Gazi University
Journal of Science
PART A: ENGINEERING AND INNOVATION
http://dergipark.org.tr/gujsa

\title{
LPG Stoklama Terminalinde Risk Değerlendirilmesi
}

\section{Risk Assessment in an LPG Storage Terminal}

\author{
Baharsu AKDAĞ $\breve{I}^{1}$, Saliha ÇETİNYOKUŞ ${ }^{2 *}$ (iD) \\ ${ }^{1}$ Gazi Üniversitesi, Kazaların Çevresel ve Teknik Araştırması Anabilim Dalı, Ankara \\ ${ }^{2}$ Gazi Üniversitesi, Kimya Mühendisliği, Ankara
}

\begin{tabular}{|c|c|}
\hline Anahtar Kelimeler & Özet \\
\hline $\begin{array}{l}\text { Risk Değerlendirmesi } \\
\text { Hata Ağacı Analizi } \\
\text { Olay Ağacı Analizi } \\
\text { HAZOP } \\
\text { Endüstriyel Kazalar }\end{array}$ & 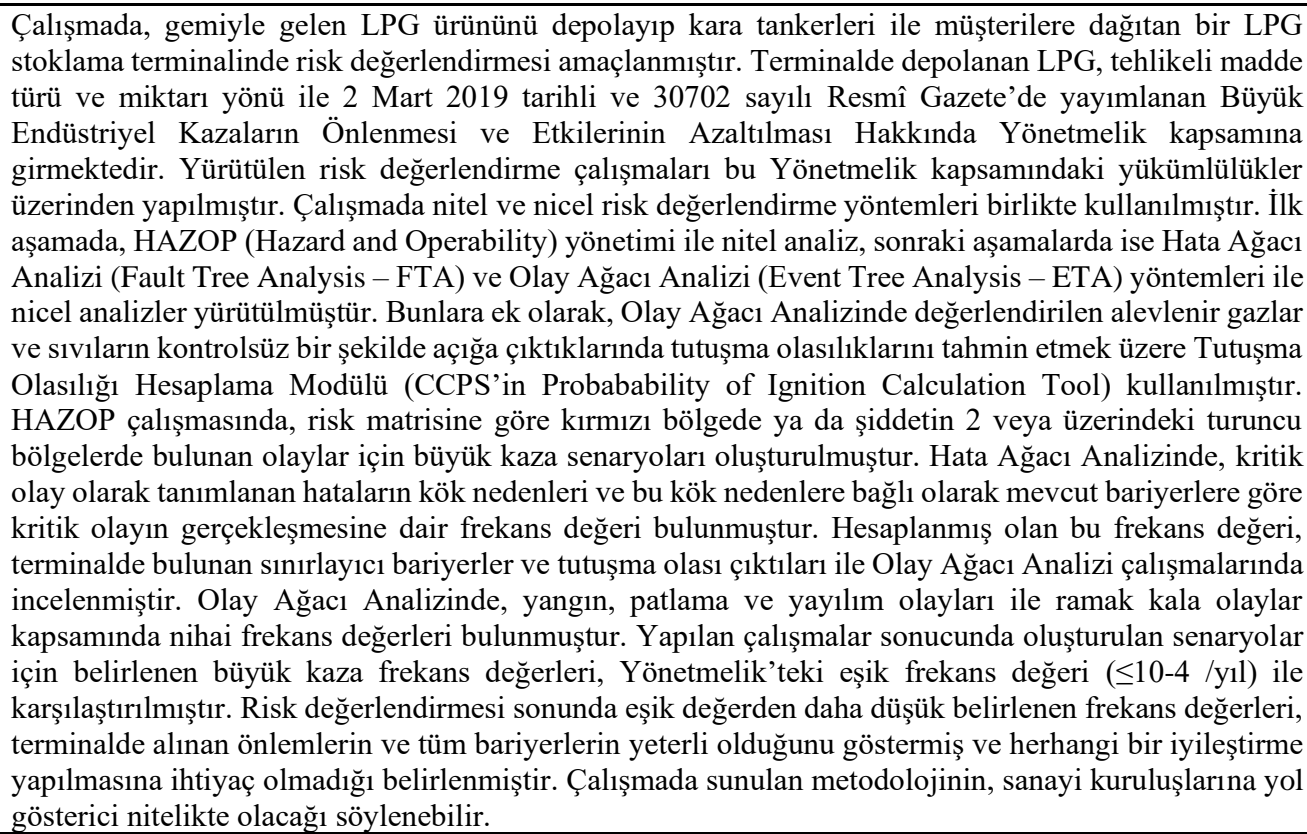 \\
\hline
\end{tabular}

\begin{tabular}{|c|c|}
\hline Keywords & Abstract \\
\hline $\begin{array}{l}\text { Risk Assessment } \\
\text { Fault Tree Analysis } \\
\text { Event Tree Analysis } \\
\text { HAZOP } \\
\text { Industrial Accidents }\end{array}$ & $\begin{array}{l}\text { In the study, risk assessment was aimed at an LPG storage terminal that stores the LPG product coming } \\
\text { by ship and distributes it to customers by land tankers. The LPG stored in the terminal is within the } \\
\text { scope of the Regulation on the Prevention of Major Industrial Accidents and Mitigation of the Effects } \\
\text { published in the Official Gazette dated March } 2,2019 \text { and numbered } 30702 \text {, in terms of the type and } \\
\text { amount of dangerous goods. The risk assessment studies performed were carried out over the obligations } \\
\text { within the scope of this Regulation. In the study, qualitative and quantitative risk assessment methods } \\
\text { were used together. In the first stage, qualitative analysis was carried out with HAZOP (Hazard and } \\
\text { Operability), and in the next stages, quantitative analyzes were carried out with Fault Tree Analysis } \\
\text { (FTA) and Event Tree Analysis (ETA) methods. Additionally, Ignition Probability Calculation Tool } \\
\text { (CCPS's Probabability of Ignition Calculation Tool) was used to estimate the ignition probabilities of } \\
\text { flammable gases and liquids evaluated in Event Tree Analysis when they were released uncontrollably. } \\
\text { In the HAZOP, major accident scenarios were created for events located in the red zone or orange zones } \\
\text { of } 2 \text { or higher severity, according to the risk matrix. In the Fault Tree Analysis, the root causes of the } \\
\text { faults defined as critical events and the frequency value for the realization of the critical event according } \\
\text { to the existing barriers were found depending on these root causes. This calculated frequency value was } \\
\text { examined in the Event Tree Analysis studies with the limiting barriers in the terminal and possible } \\
\text { ignition outputs. In the Event Tree Analysis, final frequency values were found for fire, explosion and } \\
\text { propagation events and near miss events. The major accident frequency values determined for the } \\
\text { scenarios created as a result of the studies were compared with the threshold frequency value ( } \leq 10^{-4} \\
\text { /year) in the Regulation. The frequency values determined lower than the threshold value at the end of } \\
\text { the risk assessment showed that the precautions taken at the terminal and all barriers were sufficient and } \\
\text { it was determined that no improvement was needed. It can be said that the methodology presented in the } \\
\text { study will be a guide for industrial organizations. }\end{array}$ \\
\hline
\end{tabular}




\begin{tabular}{lcc}
\hline Alıntı / Cite & & \\
\hline Akdağ, B., \& Çetinyokuş, S. (2021) LPG Stoklama Terminalinde Risk Değerlendirilmesi. GU J Sci, Part A, 8(4), 459-481. \\
\hline Yazar Kimliği / Author ID (ORCID Number) & Makale Süreci / Article Process \\
\hline B. Akdă̆, 0000-0002-4883-988X & Başvuru Tarihi / Submission Date & 06.10 .2021 \\
S. Çetinyokuş, 0000-0001-9955-6428 & Revizyon Tarihi / Revision Date & 15.11 .2021 \\
& Kabul Tarihi / Accepted Date & 08.12 .2021 \\
& Yayım Tarihi / Published Date & 10.12 .2021 \\
\hline
\end{tabular}

\section{GİRIŞ}

Son yıllarda endüstriyel üretimlerin artmasına bağlı olarak üretimlerde kullanılan kimyasal maddelerin miktarında da artış görülmektedir. Bu kimyasal maddeler birç̧ok sektörde yer edinmiş olup, sektörlerden başlıcaları maden, enerji, inşaat, tarım olarak belirtilebilir. Kimyasal maddeler sahip oldukları özellikler bakımından bazı proseslerde özel dikkat gerektirmektedir. Bu prosesler, depolama, üretim, bertaraf ve taşıma gibi süreçleri kapsamaktadır. Proseslerde yaşanabilecek hatalar sonuçları ağır olan kazaların meydana gelmesine sebep olabilir. Bu nedenle, bu prosesleri içeren tesislerde/terminallerde bazı özel risk tabanlı çalışmalar yapılması gerekmektedir.

Kimyasalların niteliğine ve miktarına bağlı olarak yaşanabilecek kazalar, endüstriyel kaza sınıfında değerlendirilmekte olup, 2 Mart 2019 tarihli ve 30702 sayılı Resmî Gazete'de yayımlanan "Büyük Endüstriyel Kazaların Önlenmesi ve Etkilerinin Azaltılması Hakkında Yönetmelik" kapsamındadır (Resmî Gazete, 2019). $\mathrm{Bu}$ yönetmelikte, büyük endüstriyel kaza, herhangi bir kuruluşun işletilmesi esnasında, kontrolsüz gelişmelerden kaynaklanan ve kuruluş içinde veya dışında insan ve/veya çevre sağlığı için anında veya daha sonra ciddi tehlikeye yol açabilen bir veya birden fazla tehlikeli maddenin sebep olduğu büyük bir yayılım, yangın veya patlama olayını ifade etmektedir. Büyük endüstriyel kazaların önlenmesi ve etkilerinin azaltılmasına dair yapılan çalışmalar proses güvenliği çalışmaları olarak adlandırılmakta olup, bu çalışmalar tehlikeli madde içeren tesisler/terminaller için büyük önem arz etmektedir. Proses güvenliği, insana, çevreye ve ekipmana olan hasarın ileri seviye analizini gerektirmektedir. Bu analizler, nitel ve nicel analizler olmak üzere risk değerlendirme çalışmalarını oluşturmaktadır. Risk değerlendirme çalışmaları sonucunda elde edilen bulgulara göre prosesin durumu göz önüne alınarak herhangi bir iyileştirmenin ihtiyaç olup olmadığına karar verilebilmektedir.

Literatürde oldukça tehlikeli LPG (Liquefied Petroleum Gas/Sıvılaştırılmış Petrol Gazı) kimyasalını içeren tank ve boru hattı etrafinda risk değerlendirme çalışmalarının yapıldığı görülmektedir. Sarvestani vd. (2021) tarafından LPG tankı geçmiş kazaları araştırılmış ve kazaları önlemek ve kontrol altına almak için çözümler sunulmuştur. Kazalar 23 hata ağacı analizi ile incelenmiştir. Kazaların \%67'sinin en az bir kazazedeye sahip olduğu, kazaların \%70'inde domino etkisi meydana geldiği belirtilmiştir. Riad vd. (2020) tarafından Cezayir'in en önemli rafinerisi olarak kabul edilen SKIKDA rafinerisinde LPG depolama tankları için D-HIGRAPH ve HAZOP (Hazard and Operability-Tehlike ve İşletilebilirlik) yöntemlerine dayalı bir çalışma yürütülmüştür. Özellikle eski olan bu tesiste güvenliği artırmak için çeşitli öneriler sunulmuş, tankın bir patlama senaryosunun termal etkisine ilişkin bazı sonuçlar paylaşılmıştır. Hosseini vd. (2020) tarafından bir gaz işleme tesisinde yangın riskini değerlendirmek için hata ağacı analizi (FTA-Fault Tree Analysis) ve olay ağacı analizi (ETAEvent Tree Analysis) geliştirilmiştir. Bulanık mantık ise uzmanların belirsiz görüşlerinden FTA'daki temel olayların olasıllğını türetmek için kullanılmıştır. Önerilen metodolojide hesaplanan risk, karar vericilerin güvenlik önlemleri ve risk azaltma konusundaki yatırımlarının maliyetine yönelik de fayda sağlamıştır. Martins \& Vianna (2020) tarafından, bir LPG küresel depolama tankı için vaka çalışması yapılmıştır. Termal radyasyonun etki yarıçapının belirlenmesi ve soğutulacak kürelerin seçiminde ALOHA (Areal Locations of Hazardous Atmospheres) yazılımı kullanılmıştır. Brezilya'da kabul edilen standartlar uluslararası standartlarla karşılaştırarak, Brezilya standartlarının yangın mühendisliğindeki ilerlemeleri değerlendirilmiştir. Akbar vd. (2019) tarafindan hem kalitatif hem de kantitatif yöntemler bir arada kullanarak bir LPG terminali için risk değerlendirmesi yapılmıştır. İlk aşamada, HAZOP ile tehlikeler belirlenmiş, sonraki aşamada FTA ve ETA kullanarak riskin olasılı̆̆ hesaplanmıştır. Şiddet seviyesi ise amaçlanan senaryoların yangın modellemesi ile elde edilmiştir. Boult (2000) tarafından, Hong Kong'daki ulaşım faaliyetlerinde LPG'nin risk yönetimi gerçekleştirilmiş, riskleri en aza indirmek için öneriler sunulmuştur. Renjith vd. (2017) tarafindan Hindistan'ın 
güney kesiminde yer alan 238 km'lik LPG boru hattı için bulanık hata ağacı analizi (TDFFTA) yürütülmüştür. 36 temel olay tanımlanmış ve bu temel olayların hata frekansları, uzaman görüşü üzerinden bulanık mantık ile oluşturulmuştur. Akyuz \& Çelik (2015) tarafından belirlenmiş görevler için insan hatası potansiyellerini sistematik olarak tahmin etmek ve LPG tanker gemilerinde gerekli güvenlik kontrol seviyelerini belirlemek için çalışmalar yürütülmüştür. LPG tanker gemilerinde kargo yükleme süreci ile birlikte insan güvenilirliğini değerlendirmek için CREAM (Bilişsel güvenilirlik ve hata analizi yöntemi) benimsemiştir. Sachan \& Premi (2015) tarafından yürütülen çalışmada, LPG'nin depolanması ve taşınması sırasında tüm süreçler analiz edilmiş, çeşitli risk değerlendirme metodolojileri kullanılmıştır. Tüm bu analizler temelinde güvenlik önerilerinde bulunulmuştur. Spoelstra vd. (2015) tarafından LPG ve propan depolama alanları için güvenlik mesafelerinin nasıl elde edilebileceği açıklanmıştır. Güvenlik mesafeleri iki ulusal standart (PGS18 ve 19) üzerinden bir BLEVE (Boiling liquid expanding vapor explosion/kaynayan sıvı genleşen buhar bulutu patlaması) olasılığını azaltacak şekilde tanımlanmıştır. Güvenliği tanımlamak için kullanılan varsayımlar tartışılmış, ulusal standartların domino etkisi olasılığını kabul edilebilir bir düzeye indirebileceği belirtilmiştir. Tauseef vd. (2010) tarafindan, LPG ve diğer basınçla sıvılaştırılmış gazlarla uğraşan büyük tesislerde BLEVE'nin tehlikelerine odaklanılmış ve BLEVE'lerin yapısı, mekanizması ve kontrol araçları tartışılmıştır. Shebeko vd. (2007) tarafından yürütülen çalışmada, büyük ölçekli petrol ihracat terminali için yangın ve patlama risk değerlendirmesi yapılmıştır. Potansiyel bireysel ve sosyal riskler hesaplanmıştır. Bireysel risk, belirli bir kişinin yangın ve patlama gibi tehlikeli faktörler tarafından yaralanma sıklığı olarak tanımlanmış, sosyal risk genellikle en az 10 kişinin yaralanması durumunda belirlenmiştir.

Farklı kimyasallar üzerinde risk değerlendirmesi yapılan çalışmalar da literatürde mevcuttur. Dinariyana vd. (2021) tarafindan Doğu Java'daki petrol şirketlerinden birinde petrol rafinerisinin sosyal risk değerlendirmesi yapılmıştır. $200 \mathrm{~mm}$ delik çapı bulunan besleme stoku tankında jet yangını için kabul edilemez risk belirlenmiş, LOPA ile sistem arızası sıklığını 1.44E-03'ten 2.88E-06'ya değiştiren bir gaz dedektörü eklenerek risk kabul edilebilir bölgeye getirilmiştir. James \& Renjith (2021) tarafından sıvılaştırılmış doğal gazın çevreye salınmasıyla sonuçlanabilecek arızaları belirlemek ve sıralamak için risk değerlendirmesi yapılmıştır. Sıvılaştırılmış doğal gaz depolama tesisinin yedi senaryosunun her bir Bağımsız Koruma Katmanının (IPL) güvenlik bütünlüğü seviye değerini bulmak için, bulanık risk matrisi ve koruma katmanı analizi (LOPA) entegresyonu yapılmıştır. HAZOP kullanılarak yedi senaryo belirlenmiş, güvenlik bütünlüğü seviyesi değeri Field Device Tool (FDT) yöntemiyle karşılaştırılmış ve risk azaltma faktörünü bulmak için risk grafiğginden yararlanılmıştır. Török vd. (2020) tarafından, bir kimya tesisi için Romanya arazi kullanım planlaması (LUP) kriterlerinin ve riske dayalı nicel yaklaşımın uygulandığı karşılaştırmalı bir vaka çalışması yapılmıştır. Klor ve propilen içeren kaza senaryoları, sonuç ve risk modelleme yazılımı ve CBS tekniği kullanılarak kapsamlı bir şekilde analiz edilmiştir. Çalışmanın karar vericiler için sahada daha sürdürülebilir ve güncel risk değerlendirme uygulamalarına yönelik bir referans çerçevesi olacağı belirtilmiştir.

$\mathrm{Bu}$ çalışmada, bir LPG stoklama terminaline dair gemiden ürün alım sırasında açığa çıkabilecek risklerin analizi yapılmış, operasyon esnasında oluşabilecek tüm tehlikeler nitel ve nicel olarak belirlenmiştir.

\section{MATERYAL VE METOT}

LPG tehlikeli kimyasalının depolandığı ve transferlerinin yapıldığı bir stoklama terminali için risk değerlendirme çalışması yürütülmüştür. LPG'nin bulunduğu sektör ve stoklama terminali enerji sektörü kapsamına girmektedir. Depolanan LPG kimyasalı ise 1sınma, tüp dolumu ve araçlarda yakıt olarak kullanılmaktadır. LPG, sıvı halde, basınç altında ve ortam sıcaklığında depolanmaktadır. Yanıcı ve parlayıcı özelliğe sahiptir ve sudaki çözünürlüğü azdır. Renksiz ve kokusuz olan LPG, herhangi bir gaz kaçağının anlaşılabilmesi için merkaptanlar ve kükürt bileşenleriyle kokulandırılmaktadır. Ürünlerin tanka transferi esnasında boru hattına enjeksiyon yapılarak bu işlem yürütülmektedir. LPG ülkemizde, karışım LPG (\%30 propan ve $\% 70$ bütan) ve propan (\%95 ve üzeri saflıkta) olarak piyasaya sürülmektedir.

TOBB'un yayınlamış olduğu Türkiye Sıvılaştırılmış Petrol Gazı Meclisi Sektör Raporunda yer alan ifadeye göre (TOBB, 2012); 2010 yılında Avrupa Komisyonu, düşük karbonlu ve karbonsuz alternatif yakıt türlerinin kısa, orta ve uzun vadede daha fazla kullanılması için inisiyatif alınması çağrısında bulunmuştur. LPG karayolu yolcu ve yük taşımacılığı ile kısa mesafeli deniz taşımacılı̆̆ında etkili bir alternatif yakıt olarak tanımlanmaktadır. Hali hazırda dünyada en fazla kullanılan alternatif yakıt olan LPG'nin, geleceğin ulaşım 
yakıtları arasında, iklim değişikliği ile mücadele de dahil olmak üzere pek çok avantaj sunduğu dile getirilmiştir. Avrupa Komisyonu'nun hazırlattığı bu rapor, elektrik, hidrojen, metan, bio ve sentetik yakıtlar gibi LPG'nin de geleceğin yakıt alternatifleri içinde giderek daha önem kazanacağını vurgulamaktadır. Diğer alternatif yakıtların yüksek yatırım maliyetlerine kıyasla LPG'nin oto gaz olarak kullanımının, yeni ve büyük yatırımlar gerektirmemekte olduğu görülmektedir.

Analiz edilen LPG stoklama terminali, gemiden terminalde yer alan depolama tanklarına ürün alarak, depolama sonrası müşteri taleplerine göre kara tankerleri ile dağıtım yapmaktadır. Terminalde depolanan LPG kimyasalının endüstriyel kaza potansiyeli bulunmaktadır. Endüstriyel kaza riskleri, jet yangını, buhar bulutu patlaması, parlama yangını ve yayılım şeklinde sonuçlanabilmektedir. Tüm bu riskler dikkate alınarak terminal için herhangi bir kazaya sebep olabilecek durumlar belirlenmiş ve analiz edilmiş, çevreye, insana ve ekipmana zararı önlemek için risk değerlendirme çalışmaları yapılmıştır.

\subsection{Risk Değerlendirmesi}

\subsection{1. Ön Hazırlık}

\section{$\underline{\text { Varsayımlar }}$}

Nitel ve nicel risk değerlendirmesi çalışmaları, Büyük Endüstriyel Kazaların Önlenmesi ve Etkilerinin Azaltılması Hakkında Yönetmelik (Resmî Gazete, 2019) kapsamında gerçekleştirilmiştir. Yönetmelik Madde 8 'de yer alan "Büyük Kaza Senaryo Dokümanı" ve buna dair yayınlanmış olan Büyük Endüstriyel Kazalarla İlgili Hazırlanacak Büyük Kaza Senaryo Dokümanı Tebliği (Resmî Gazete, 2020) dikkate alınarak çalışmalar yapılmıştır. Çalışmaların yapıldığı yer örnek bir LPG stoklama terminalidir. Terminalde sadece mix (LPG) depolaması yapıldığ1 göz önünde bulundurulmuştur.

\section{$\underline{\text { Sinirlar }}$}

Terminalde gemi ile LPG ürünü alınıp daha sonra kara tankerleriyle dağıtımı yapılmaktadır. Çalışmada, terminaldeki operasyonlar içerisinden gemiden T-001 nolu küre tanka mix (LPG) transferi değerlendirilmiştir. Tank ve boru hatları tehlikeli ekipmandır. Yalnızca operasyonel çalışmalar değerlendirilmiş olup harici tehlikeler (sel, deprem, toprak kayması, yıldırım, komşu kuruluştan kaynaklanabilecek tehlikeler) ve sabotaj bu çalışmanın kapsamına dahil edilmemiştir.

\section{İs Yerinin Tanıtımı}

Terminalin ana faaliyet konusu, LPG'nin gemilerden elleçlenerek depolama tanklarına alınması ve kara tankerlerine dolumunun yapılması olup tankerler aracılığı ile müşterilere gönderimi sağlanmaktadır. Terminalde her biri $3000 \mathrm{~m}^{3}$ olan 4 adet LPG tankı bulunmaktadır. Tesise ait iş akış şeması Şekil 1'de sunulmuştur.

Tesiste gerçekleşen operasyonlar aşağıdaki gibidir:

Gemiden T-001 Nolu Küre Tanka Mix (LPG) Transferi,

Tanktan Tankere Mix (LPG) Transferi,

Küre Tanktan Küre Tanka Mix (LPG) Transferi

Tankerden T-001 Nolu Tanka Mix (LPG) Transferi (Kompresör ile)

Daha sonra tankerler aracılığı ile müşterilere ikmal yapılmaktadır. 


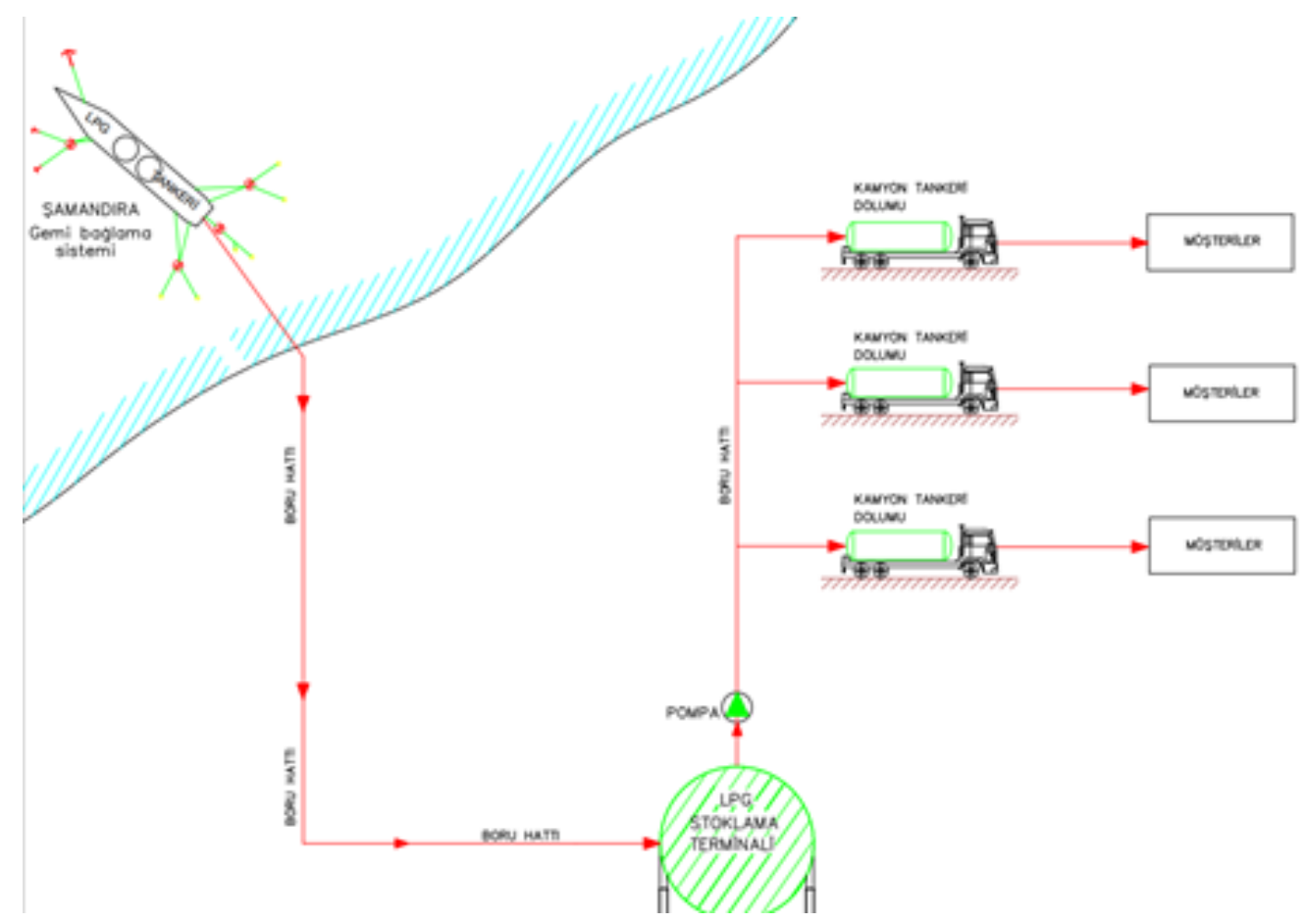

Şekil 1. LPG Stoklama Terminali İş Aklş Şeması

$\underline{\text { Kullanılan İș Ekipmanları }}$

Terminalde 4 adet her biri $3000 \mathrm{~m}^{3}$ olan LPG depolama tankları bulunmaktadır. Buna ek olarak operasyonlar sırasında kullanılan iş ekipmanları aşağıda listelenmiştir:

- Transfer hatları (boru hatları)

- Ürün aktarımının sağlanması için $150 \mathrm{~m}^{3} / \mathrm{saat}$ debiye sahip 3 adet pompa

- Transfer hatları üzerinde herhangi bir basıncın yaşanmasına bağlı olarak operasyonu güvenli hale getirmek amacıyla hatta biriken basıncı dışarı veren basınç tahliye vanaları

- Tanklardaki seviyeyi ölçmek için kullanılan her bir tanka sabitlenen seviye transmitteri

- Tanklardaki basıncı ölçmek için kullanılan her bir tanka sabitlenen basınç transmitteri

- Ürün transfer esnasında hatlarda yer alan motorlu ve manuel vanalar

- Operasyonların takip edilmesini sağlayan kontrol lojik ünite (PLC)

\section{$\underline{\text { Kullanilan Kimyasallar }}$}

Terminalde yalnızca LPG depolaması yapılmakta olup acil durumlarda kullanılmak amacı ile terminalde bulunan jeneratörün çalıştırılması için az miktarda dizel yakıt da bulunmaktadır. LPG, Büyük Endüstriyel Kazaların Önlenmesi ve Etkilerinin Azaltılması Hakkında Yönetmelik Ek-1, Tablo 2/18'de yer almaktadır (Resmî Gazete, 2019).

\section{$\underline{\text { Risk Değerlendirmesinin Amac1 }}$}

Terminal için yapılan risk değerlendirmesi çalışmalarının amacı; Büyük Endüstriyel Kazaların Önlenmesi ve Etkilerinin Azaltılması Hakkında Yönetmelik (Resmî Gazete, 2019), Madde 9'da verilen büyük kaza frekans değerinin $\left(\leq 10^{-4} / y ı 1\right)$ sağlanıp sağlanmadığının tespitidir. Risk değerlendirme çalışmaları sonucunda belirtilen frekans değeri, ilgili eşik değer ile karşılaştırılarak terminalde endüstriyel kazalara yönelik iyileştirme ihtiyacının olup olmadığına karar verilebilecek ve terminal güvenli hale getirilebilecektir.

\section{$\underline{\text { Seçilen Risk Değerlendirme Yöntemleri }}$}

Çalışmada uygulanan risk değerlendirme yöntemleri sırasıyla aşağıda verilmiştir: 
Belirlenen tehlikeli ekipmanlar için operasyon esnasında ortaya çıkabilecek dahili tehlikelere yönelik önce nitel çalışmalar yürütülmüş, HAZOP (Hazard and Operability) analizinden yararlanılmıştır.

Ardından Hata Ağacı Analizi (Fault Tree Analysis - FTA) ve Olay Ağacı Analizi (Event Tree Analysis - ETA) kullanılarak nicel analiz çalışmaları yapılmıştır.

Hata Ağacı Analizi’nin çözümlenmesinde "TOP Event FTA” yazılımı kullanılmıştır. Bu yazılımın kullanım amacı, karmaşık senaryolarda Minimal Kesit Seti ve İkili Karar Diyagramı kullanılarak ağacın çözümlenmesidir. Yazılımda tanımlanan hata ağacındaki tüm kök nedenlerin hata frekansı veya hata olasılı̆̆1 verileri bulunarak kritik olayın frekansı hesaplanmıştır. Kritik olayı takip eden farklı büyük kaza senaryolarının frekans değerini hesaplamak için Olay Ağacı Analizi kullanılmıştır. Olay Ağacı Analizi’nin çözümlenmesinde ise "LOGAN" yazılımından yararlanılmıştır.

\section{$\underline{\text { Kullanilan Veriler }}$}

HAZOP çalışması kapsamında; operasyon sırasında pompanın debisi, operasyon basıncı, tankın maksimum olabileceği kapasite ve basınç tahliye vanalarının açıldığı basınç gibi veriler terminalden sağlanmıştır. Ayrıca, CCPS (Center for Chemical Process Safety - AIChE) tarafından oluşturulan Tutuşma Olasılığı Hesaplama Modülü kullanılarak operasyon sırasında kullanılan kimyasalın tutuşma olasılıkları hesaplanmıştır (CCPS, 2014). Elde edilen değerler, Olay Ağacı Analizinde kullanılmıştır. Buna ek olarak, ekipmanların hatalarına dair olasılık ve frekans değerleri terminalden temin edilmiş, Hata Ağacı Analizi çalışmaları sırasında kullanılmıştır. Tesisteki ekipmanların bakım sıklığ 1 yılda 1 olarak değerlendirilmiştir.

\subsubsection{Uygulama}

\section{$\underline{\text { HAZOP Analizi }}$}

HAZOP, tesiste bulunan tehlikeli ekipmanlar üzerinden yapılmışır. HAZOP, kalitatif bir teknik olup, tasarım, proses, prosedür veya sistemin her aşamasında, tasarım amacının veya işletme koşullarının nasıl sağlanamayacağını sorgulayan rehber kelimeleri temel alır (TSE, 2016). HAZOP, "tasarım" ve incelenecek proses, sistem veya prosedür özelliklerini ele alıp bunların her parçasını gözden geçirerek, ne tür performans sapmaları ve muhtemel sonuçları olabileceğini bulmaya çalışır. Bu da sistemin, prosesin veya prosedürün her bir parçasının proses parametrelerindeki değişime nasıl tepki vereceği, uygun rehber / yardımcı kelimelerin uygulanması ve sistematik olarak incelenmesi ile elde edilir. Yardımc1 kelimeler belirli bir sistem, proses veya prosedüre uyarlanabilir ya da her türlü farklılaşmayı içerecek genel kelimeler kullanılabilir (TSE, 2010). HAZOP çalışması içerisinde her bir sapma için BS ISO/IEC 27005:2008 standardındaki matris (Tablo 1), kullanılarak nitel risk değerlendirme çalışması yapılmıştır. Matriste " $F$ " harfi frekans kodlarını, "S" harfi ise şiddet kodlarını temsil etmektedir. Bu risk matrisi, 3 gruba ayrılmış tehlike kategorileri için (insana olan zarar, çevreye verilen zarar ve mala olan hasar) ayrı ayrı uygulanmıştır. Risk skoru belirlenirken frekans değeri ile şiddet değerinin kesişimleri kullanılmıştır. Risk matrisine göre kırmızı bölgede ya da şiddetin 2 veya üzerindeki turuncu bölgelerde bulunan olaylar için bir sonraki adım olan büyük kaza senaryolarının oluşturulması, analizi ve değerlendirilmesine geçilmiştir.

Tablo 1. Risk Matrisi

\begin{tabular}{|c|c|c|c|c|c|}
\hline F4 & 4 & 5 & 6 & 7 & 8 \\
\hline F3 & 3 & 4 & 5 & 6 & 7 \\
\hline F2 & 2 & 3 & 4 & 5 & 6 \\
\hline F1 & 1 & 2 & 3 & 4 & 5 \\
\hline F0 & 0 & 1 & 2 & 3 & 4 \\
\hline & S0 & S1 & S2 & S3 & S4 \\
\hline
\end{tabular}

$F=$ Frekans Kodu $S=$ Şiddet Kodu 
Tablo 1'de yer alan frekans kodları, tehlike kategori kodları ve şiddet kodları aşağıda sunulmuştur.

\section{Frekans Kodları:}

[0] Olasılık o kadar düşük ki, ortaya çıkmayacağı varsayılabilir.

[1] Olasılık düşük olmasına rağmen sistemin hayatı boyunca ortaya çıkabilir.

[2] Sistemin hayatı boyunca birkaç kez ortaya çıkabilir.

[3] Sistemin hayatı boyunca defalarca ortaya çıkabilir.

[4] S1k s1k meydana gelebilir.

Tehlike Kategori Kodları:

[1] Çalışanlara Olan Zarar

[2] Çevreye Verilen Zarar

[3] Ekipmana/Mala Olan Hasar

\section{Siddet Kodları:}

[0] Önemsiz

[1] Küçük

[2] Ciddi

[3] Büyük

\section{[4] Katastrofik}

İlgili matris ve kodlar ile oluşturulan şiddet/tehlike kategorisi matrisi Tablo 2'de sunulmuştur.

Tablo 2. Şiddet / Tehlike Kategori Matrisi

\begin{tabular}{|c|c|c|c|c|c|}
\hline & $\begin{array}{c}0 \\
\text { Önemsiz }\end{array}$ & $\begin{array}{c}1 \\
\text { Küçük }\end{array}$ & $\begin{array}{c}2 \\
\text { Ciddi }\end{array}$ & $\begin{array}{c}3 \\
\text { Büyük }\end{array}$ & $\begin{array}{c}4 \\
\text { Katastrofik }\end{array}$ \\
\hline $\begin{array}{c}1 \\
\text { Insana } \\
\text { Olan } \\
\text { Zarar }\end{array}$ & $\begin{array}{c}\text { İnsana zarar } \\
\text { vermez }\end{array}$ & $\begin{array}{c}\text { Tesis içerisinde } 1 \\
\text { kişinin hafif } \\
\text { yaralanmasina sebep } \\
\text { olur }\end{array}$ & $\begin{array}{c}\text { Tesis içerisindeki } 1 \\
\text { kişinin ölümü veya } 6 \\
\text { kişinin yaralanması / } \\
\text { Tesis dışındaki } 1 \\
\text { kişinin yaralanması }\end{array}$ & $\begin{array}{l}\text { Tesis içerisindeki } \\
\text { tüm popülasyon } \\
\text { kaybedilir }\end{array}$ & $\begin{array}{c}\text { Bölgesel } \\
\text { popülasyonu etkiler } \\
\text { ve toplu ölümlere } \\
\text { sebep olur }\end{array}$ \\
\hline $\begin{array}{c}2 \\
\text { Çevreye } \\
\text { Verilen } \\
\text { Zarar }\end{array}$ & $\begin{array}{c}\text { Çevreye zarar } \\
\text { vermez }\end{array}$ & $\begin{array}{c}\text { Karasal ve su } \\
\text { habitata geçici ve } \\
\text { geri dönülebilir etki }\end{array}$ & $\begin{array}{c}\text { Tesis sınırları } \\
\text { içerisinde karasal ve } \\
\text { su habitata uzun } \\
\text { süreli hasar }\end{array}$ & $\begin{array}{c}\text { Tesis sınırları } \\
\text { içerisinde karasal ve } \\
\text { su habitata kalıcı } \\
\text { hasar }\end{array}$ & $\begin{array}{l}\text { Tesis sınırları dışına } \\
\text { taşan karasal ve su } \\
\text { habitata kalıcı hasar }\end{array}$ \\
\hline $\begin{array}{c}3 \\
\text { Mala } \\
\text { Olan } \\
\text { Hasar }\end{array}$ & $\begin{array}{l}\text { Mala hasar } \\
\text { vermez }\end{array}$ & $\begin{array}{c}\text { Tesisteki 5M TL / } \\
\text { Tesis dışı 2M TL'den } \\
\text { az hasar }\end{array}$ & $\begin{array}{l}\text { Tesisteki 5M TL / } \\
\text { Tesis dişı 2M TL } \\
\text { hasar }\end{array}$ & $\begin{array}{l}\text { Tesisteki 5M TL'den } \\
\text { fazla hasar }\end{array}$ & $\begin{array}{l}\text { Tesis dişı 2M TL'den } \\
\text { fazla hasar }\end{array}$ \\
\hline
\end{tabular}


Tablo 2, Büyük Endüstriyel Kazaların Önlenmesi ve Etkilerinin Azaltılması Hakkında Yönetmelik Ek-6 Büyük Endüstriyel Kaza Bildirim Kriterleri’ne göre hazırlanmıştır (Resmî Gazete, 2019).

HAZOP analizinde kullanılan varsayımlar aşağıda sıralanmıştır:

- Proses ekipmanı, enstrümantasyon ve emniyet cihazlarındaki arızalar rastgele meydana gelir.

- Emniyet cihazlarının arıza oranları ve talep oranları düşük kabul edilir.

- Ekipmanı tamir etme veya bakım yapma süresi ihmal edilebilir olarak kabul edilir.

- Tesis, emniyetle ilgili iyi yönetim sistemi ve mühendislik standartlarına göre tasarlanmış, çalıştırılmış ve bakımı yapılmıştır.

- Bir arızayı tehlikeli yapan en önemli faktör, o arızanın farkında olunmamasıdır. Yani arızanın gizli olmasidir.

- Bir alarma insan tepki süresi en az 2 dakika olarak kabul edilir. Bu nedenle operatöre 2 dakikadan daha az süre veren alarmlar etkin bariyer olarak dikkate alınmaz.

- Paralel işletilen özdeş sistemler için tek bir sistem analiz edilip bulgular diğer sistemlere de uygulanır.

\section{$\underline{\text { Hata Ağacı Analizi }}$}

Hata ağacı analizi, belirli bir istenmeyen olaya ("kritik olay" olarak adlandırılır.) neden olan faktörleri tanımlamak ve analiz etmek için kullanılan bir tekniktir. Nedensel faktörler tümden gelimli olarak tanımlanır, mantıksal biçimde organize edilir ve mantıksal faktörler ve bunların kritik olayla mantıksal ilişkisi şekilsel olarak bir ağaç diyagramında sunulur. Hata ağacında tanımlanan faktörler; istenmeyen olaylara sebebiyet veren donanım bileşen hatası, insan hatası veya diğer alakalı olaylar ile ilişkilendirilmiş olaylar olabilir (TSE, 2016). Yönetmeliğin 9 uncu maddesinde yer alan büyük endüstriyel kaza frekansının sınır değeri ile karşılaş̧ırma yapmaya elverişli sonuçlar üretilebilmesi için hata ağacındaki tüm kök nedenlerin hata frekansları veya hata olasılığ 1 verileri bulunmuştur.

\section{Olay Ağacı Analizi}

Olay ağacı analizi, kritik olayı takip eden farklı kaza senaryolarının frekans değerini hesaplamak için kullanılmıştır. Hata ağacı analizinden farklı olarak olay ağacı analizinde tümevarım mantığı vardır. Bu analiz, nitel veya nicel olarak uygulanabilir, çalışmada nicel uygulama gerçekleştirilmiştir. Olay ağacı bir kritik olayın seçilmesi ile başlar. Daha sonra sonuçları en aza indirmek için mevcut bulunan fonksiyonlar ve sistemler sıra ile listelenir. Olay ağacı analizi, ikili sistem üzerinden yürümektedir. Her bir fonksiyon veya sistem için, bu fonksiyon veya sistemlerin başarısını ya da hatasını gösteren bir çizgi çizilir. Her çizgiye hatanın olasılığı atanır bu yolla kritik olaydan çıkan farklı sonuçlar değerlendirilebilir (TSE, 2010).

\section{BULGULAR VE TARTIŞMA}

\subsection{HAZOP Analizi}

Şiddet / Tehlike Kategori Matrisi ile Risk Matrisi temel alınarak LPG stoklama terminalinde yapılan HAZOP çalışması Tablo 3'te sunulmuştur.

HAZOP çalışma sonucu kırmızı bölgede ya da şiddetin 2 veya üzerindeki turuncu bölgelerde bulunan olaylar için büyük kaza senaryoları oluşturulmuştur. LPG stoklama terminali için oluşturulan senaryo listesi Tablo 4'te verilmiştir. 
Tablo 3. Terminal için Yapılan HAZOP Analizi

\begin{tabular}{|c|c|c|c|c|c|}
\hline \multicolumn{6}{|c|}{$\begin{array}{l}\text { NOD: } 1 \\
\text { İNCELENEN TARİH: } 21.12 .2020\end{array}$} \\
\hline \multicolumn{6}{|c|}{ PARÇA: Gemiden T-001 Nolu Küre Tanka LPG Transferi } \\
\hline \multicolumn{6}{|c|}{$\begin{array}{l}\text { LPG; gemiden T-001 nolu tanka, gem } \\
\text { basınçta ve ortam sicaklığında transfe }\end{array}$} \\
\hline \multicolumn{6}{|c|}{ ÇIZIMLLER VE DOKÜMANLAR } \\
\hline \multicolumn{6}{|c|}{ LPG STOKLAMA TERMINALİ P\&ID 202301-1 } \\
\hline \multicolumn{6}{|c|}{ LPG STOKLAMA TERMINALİ P\&ID 202301-2 } \\
\hline \multicolumn{6}{|c|}{ LPG STOKLAMA TERMINALİ P\&ID 202301-3 } \\
\hline \multicolumn{6}{|c|}{ LPG STOKLAMA TERMINALİ P\&ID 202301-4 } \\
\hline NO & SAPMA & NEDEN & SONUÇ & BARIYER & EYLEMLER \\
\hline 1 & $\begin{array}{l}\text { BASINÇ } \\
\text { FAZLA }\end{array}$ & $\begin{array}{l}\text { Hidrolik güç ünitesi } \\
\text { (HGÜ) sisteminde yer } \\
\text { alan hatlarda kaçak } \\
\text { olması }\end{array}$ & $\begin{array}{l}\text { Hidrolik vananın kapanması } \\
\text { sonucu hatta basıncın artması } \\
\text { ile hat üzerinde bulunan basınç } \\
\text { tahliye vanalarından atmosfere } \\
\text { LPG salınımı ve tutuşturucu } \\
\text { kaynak varlığında parlama / } \\
\text { patlama meydana gelmesi } \\
\text { Frek: [4] } \\
\text { Ktgr: [1] [2] [3] } \\
\text { Şiddt: [2] [1] [2] } \\
\text { Risk: [6] [5] [6] }\end{array}$ & $\begin{array}{l}\text { 1- Hidrolik güç ünitesinde yer } \\
\text { alan basınç transmitterinden } \\
\text { alınan düşük basınç verisi ile } \\
\text { operatör sisteminin kontrolünü } \\
\text { yapar ve gerekli durumda } \\
\text { gemiye haber vererek } \\
\text { operasyonun durmasını sağlar. } \\
\text { 2- Hidrolik güç ünitesinde yer } \\
\text { alan manuel pompa basınç } \\
\text { sivicinden alınan veri ile } \\
\text { operatör tarafindan devreye } \\
\text { alınır. }\end{array}$ & $\begin{array}{l}\text { Nicel risk analizi çalış̧malarında } \\
\text { değerlendirilmiş olup detaylar } \\
\text { FTA 01 / ETA 01'de yer } \\
\text { almaktadır. }\end{array}$ \\
\hline 2 & $\begin{array}{l}\text { BASINÇ } \\
\text { FAZLA }\end{array}$ & $\begin{array}{l}\text { Motorlu kelebek vananın } \\
\text { talep anında açılmaması }\end{array}$ & $\begin{array}{l}\text { Motorlu kelebek vananın kapalı } \\
\text { kalması sonucu hatta basıncın } \\
\text { artması ile hat üzerinde bulunan } \\
\text { basınç tahliye vanalarından } \\
\text { atmosfere LPG salınımı ve } \\
\text { tutuşturucu kaynak varlığında } \\
\text { parlama / patlama meydana } \\
\text { gelmesi } \\
\text { Frek: [4] } \\
\text { Ktgr: [1] [2] [3] } \\
\text { Şiddt: [2] [1] [2] } \\
\text { Risk: [6] [5] [6] }\end{array}$ & \begin{tabular}{|l|} 
Seviye transmitteri verisi ile \\
seviyenin artmadığı sistemden \\
(kontrol lojik ünite) operatör \\
tarafindan gözlemlenir, gemi ile \\
iletişime geçilerek operasyon \\
durdurulur.
\end{tabular} & $\begin{array}{l}\text { Nicel risk analizi çalış̧malarında } \\
\text { değerlendirilmiş olup detaylar } \\
\text { FTA } 01 \text { / ETA 01'de yer } \\
\text { almaktadır. }\end{array}$ \\
\hline 3 & $\begin{array}{l}\text { BASINÇ } \\
\text { FAZLA }\end{array}$ & $\begin{array}{l}\text { Frekans konventörü hatası } \\
\text { sonucu gemi pompasının } \\
\text { yüksek debide çalışması }\end{array}$ & $\begin{array}{l}\text { Hatta basınç artışı yaşanması } \\
\text { Frek: [4] } \\
\text { Ktgr: [1] [2] [3] } \\
\text { Şiddt: [0] [0] [0] } \\
\text { Risk: [4] [4] [4] } \\
\end{array}$ & \begin{tabular}{|l|} 
Sayaç sisteminde yer akış \\
transmitteri verisi ile akış hızı \\
kontrol edilir. Gerekli durumda \\
operatör gemi ile iletişime \\
geçerek operasyonu durdurur. \\
\end{tabular} & $\begin{array}{l}\text { Risk skoru göz önüne alındığında } \\
\text { kabul edilebilir seviyede olması } \\
\text { nedeniyle nicel risk değerlendirme } \\
\text { çalışmalarında } \\
\text { değerlendirilmemiştir. }\end{array}$ \\
\hline 4 & $\begin{array}{l}\text { BASINÇ } \\
\text { FAZLA }\end{array}$ & $\begin{array}{l}\text { Operatör hatası nedeniyle } \\
\text { hat üzerinde bulunan } \\
\text { manuel vananın kapalı } \\
\text { olması }\end{array}$ & $\begin{array}{l}\text { Hatta basıncın artması ile hat } \\
\text { üzerinde bulunan basınç tahliye } \\
\text { vanalarından atmosfere LPG } \\
\text { salınımı ve tutuşturucu kaynak } \\
\text { varlığında parlama / patlama } \\
\text { meydana gelmesi } \\
\text { Frek: [4] } \\
\text { Ktgr: [1] [2] [3] } \\
\text { Şiddt: [2] [1] [2] } \\
\text { Risk: [6] [5] [6] }\end{array}$ & & $\begin{array}{l}\text { Nicel risk analizi çalışmalarında } \\
\text { değerlendirilmiş olup detaylar } \\
\text { FTA 01 / ETA 01'de yer } \\
\text { almaktadır. }\end{array}$ \\
\hline 5 & $\begin{array}{l}\text { BASINÇ } \\
\text { FAZLA }\end{array}$ & $\begin{array}{l}\text { Deniz altındaki boru } \\
\text { hattının diş kaynaklı } \\
\text { sebeplerle ezilerek boru } \\
\text { çapında daralma meydana } \\
\text { gelmesi }\end{array}$ & $\begin{array}{l}\text { Ezilme öncesi hatta basıncın } \\
\text { artması ile boru hattının zayıf } \\
\text { noktasından denize LPG } \\
\text { sizıntısı ve tutuşturucu kaynak } \\
\text { varlı̆ında parlama / patlama } \\
\text { meydana gelmesi } \\
\text { Frek: [4] } \\
\text { Ktgr: [1] [2] [3] } \\
\text { Şiddt: [2] [1] [2] } \\
\text { Risk: [6] [5] [6] }\end{array}$ & \begin{tabular}{|l|} 
1- Seviye transmitteri verisi ile \\
seviyenin artmadığ sistemden \\
(kontrol lojik ünite) operatör \\
tarafindan gözlemlenir, gemi ile \\
iletişime geçilerek operasyon \\
durdurulur. \\
2- Sayaç sisteminde yer akış \\
transmitteri verisi ile akış hızı \\
kontrol edilir. Gerekli durumda \\
operatör gemi ile iletişime \\
geçerek operasyonu durdurur. \\
\end{tabular} & $\begin{array}{l}\text { Nicel risk analizi çalış̧malarında } \\
\text { değerlendirilmiş olup detaylar } \\
\text { FTA 02 / ETA 02'de yer } \\
\text { almaktadır. }\end{array}$ \\
\hline 6 & \begin{tabular}{|l} 
BASINÇ \\
FAZLA
\end{tabular} & $\begin{array}{l}\text { Bakım / test esnasında } \\
\text { boru hattında yabancı bir } \\
\text { parçanın unutulması veya } \\
\text { gemi kaynaklı yabancı } \\
\text { maddenin hatta girmesi }\end{array}$ & $\begin{array}{l}\text { Hatta basınç artışı yaşanması } \\
\text { Frek: [4] } \\
\text { Ktgr: [1] [2] [3] } \\
\text { Şiddt: [0] [0] [0] } \\
\text { Risk: [4] [4] [4] }\end{array}$ & & $\begin{array}{l}\text { Risk skoru göz önüne alındığında } \\
\text { kabul edilebilir seviyede olması } \\
\text { nedeniyle nicel risk değerlendirme } \\
\text { çalışmalarında } \\
\text { değerlendirilmemiştir. }\end{array}$ \\
\hline
\end{tabular}


Tablo 3. (Devam ediyor)

\begin{tabular}{|c|c|c|c|c|c|}
\hline \begin{tabular}{|l|l}
7 \\
\end{tabular} & \begin{tabular}{|l} 
BASINÇ \\
FAZLA
\end{tabular} & \begin{tabular}{|l|} 
Operatör hatası nedeniyle \\
gemi pompasının \\
çıkışında yer alan by-pass \\
vanasının yanlış \\
ayarlanması ile yüksek \\
debide hatta ürün \\
verilmesi
\end{tabular} & $\begin{array}{l}\text { Hatta basınç artışı yaşanması } \\
\text { Frek: [4] } \\
\text { Ktgr: [1] [2] [3] } \\
\text { Şiddt: [0] [0] [0] } \\
\text { Risk: [4] [4] [4] }\end{array}$ & $\begin{array}{l}\text { Sayaç sisteminde yer akış } \\
\text { transmitteri verisi ile akış hızı } \\
\text { kontrol edilir. Gerekli durumda } \\
\text { operatör gemi ile iletişime } \\
\text { geçerek operasyonu durdurur. }\end{array}$ & $\begin{array}{l}\text { Risk skoru göz önüne alındığında } \\
\text { kabul edilebilir seviyede olması } \\
\text { nedeniyle nicel risk değerlendirme } \\
\text { çalışmalarında } \\
\text { değerlendirilmemiştir. }\end{array}$ \\
\hline 8 & $\begin{array}{l}\text { BASINÇ } \\
\text { AZ }\end{array}$ & $\begin{array}{l}\text { Gemi pompasının düşük } \\
\text { debide çalışması }\end{array}$ & \begin{tabular}{|l} 
İşletilebilirlik problemi \\
yaratmas1 \\
Frek: $[4]$ \\
Ktgr: $[1][2][3]$ \\
Şiddt: [0] [0] [0] \\
Risk: $[4][4][4]$ \\
\end{tabular} & & $\begin{array}{l}\text { Risk skoru göz önüne alındığında } \\
\text { kabul edilebilir seviyede olması } \\
\text { nedeniyle nicel risk değerlendirme } \\
\text { çalışmalarında } \\
\text { değerlendirilmemiştir. }\end{array}$ \\
\hline 9 & $\begin{array}{l}\text { BASINÇ } \\
\text { AZ }\end{array}$ & \begin{tabular}{|l} 
Deniz altındaki boru \\
hattının dış kaynaklı \\
sebeplerle ezilerek boru \\
çapında daralma olması
\end{tabular} & \begin{tabular}{|l|} 
Operasyon süresinin uzamasi \\
ile işletilebilirlik problemi \\
yaratmas1 \\
Frek: [4] \\
Ktgr: [1] [2] [3] \\
Şiddt: $[0][0][0]$ \\
Risk: $[4][4][4]$ \\
\end{tabular} & \begin{tabular}{|l|} 
Sayaç sisteminde yer akış \\
transmitteri verisi ile akış hızı \\
kontrol edilir. Gerekli durumda \\
operatör gemi ile iletişime \\
geçerek operasyonu durdurur.
\end{tabular} & $\begin{array}{l}\text { Risk skoru göz önüne alındığında } \\
\text { kabul edilebilir seviyede olması } \\
\text { nedeniyle nicel risk değerlendirme } \\
\text { çalışmalarında } \\
\text { değerlendirilmemiştir. }\end{array}$ \\
\hline 10 & \begin{tabular}{|l} 
SEVIYY \\
FAZLA
\end{tabular} & \begin{tabular}{|l|} 
İnsan hatası sonucu yanlış \\
hesaplama yapılması ve \\
LPG tankına fazla ürün \\
transferi
\end{tabular} & $\begin{array}{l}\text { Tank seviyesinin yükselmesi ile } \\
\text { tankta yer alan basınç tahliye } \\
\text { vanalarından atmosfere gaz } \\
\text { fazda LPG'nin salınımı ve } \\
\text { tutuşturucu kaynak varlığında } \\
\text { parlama / patlama meydana } \\
\text { gelmesi } \\
\text { Frek: [3] } \\
\text { Ktgr: [1] [2] [3] } \\
\text { Şiddt: [2] [1] [2] } \\
\text { Risk: [5] [4] [5] }\end{array}$ & $\begin{array}{l}\text { 1-Gemi manifold basıncının } \\
\text { yükselmesi sebebiyle operatör } \\
\text { müdahalede bulunur. } \\
\text { 2- Seviye transmitteri verisi ile } \\
\text { seviyenin yükseldiği } \\
\text { sisteminden (kontrol lojik } \\
\text { ünite) operatör tarafından } \\
\text { gözlemlenir, gemi ile iletişime } \\
\text { geçilerek operasyon durdurulur. } \\
\text { 3- Seviye transmitteri verisi ile } \\
\text { seviyenin yükseldiği } \\
\text { sisteminden (kontrol lojik } \\
\text { ünite) gemi operatör tarafindan } \\
\text { gözlemlenir, operasyon } \\
\text { durdurulur. } \\
\text { 4- Seviye transmitteri verisi ile } \\
\text { seviyenin yükseldiği } \\
\text { sisteminden (kontrol lojik } \\
\text { ünite) güvenlik tarafindan } \\
\text { gözlemlenir, gemi ile iletişime } \\
\text { geçilerek operasyon durdurulur. } \\
\text { 5- Seviye transmitteri verisi ile } \\
\text { dolum yapılan tankın motorlu } \\
\text { vanası kapanır ve diğer tankın } \\
\text { motorlu vanasını açlır. }\end{array}$ & $\begin{array}{l}\text { Nicel risk analizi çalışmalarında } \\
\text { değerlendirilmiş olup detaylar } \\
\text { FTA 03 / ETA 03'te yer } \\
\text { almaktadır. }\end{array}$ \\
\hline 11 & $\begin{array}{l}\text { SEVIYY } \\
\text { AZ }\end{array}$ & \begin{tabular}{|l|} 
İnsan hatası sonucu yanlış \\
hesaplama yapılması ve \\
LPG tankına az ürün \\
transferi
\end{tabular} & \begin{tabular}{|l} 
İşletilebilirlik problemi \\
yaratması \\
Frek: [4] \\
Ktgr: [1] [2] [3] \\
Şiddt: [0] [0] [0] \\
Risk: $[4][4][4]$ \\
\end{tabular} & & $\begin{array}{l}\text { Risk skoru göz önüne alındığında } \\
\text { kabul edilebilir seviyede olması } \\
\text { nedeniyle nicel risk değerlendirme } \\
\text { çalışmalarında } \\
\text { değerlendirilmemiştir. }\end{array}$ \\
\hline 12 & $\begin{array}{l}\text { AKIŞ } \\
\text { YOK }\end{array}$ & $\begin{array}{l}\text { Gemi pompasının } \\
\text { çalışmaması }\end{array}$ & $\begin{array}{l}\text { İşletilebilirlik problemi } \\
\text { yaratması } \\
\text { Frek: [4] } \\
\text { Ktgr: [1] [2] [3] } \\
\text { Şiddt: [0] [0] [0] } \\
\text { Risk: [4] [4] [4] } \\
\end{array}$ & & $\begin{array}{l}\text { Risk skoru göz önüne alındığında } \\
\text { kabul edilebilir seviyede olması } \\
\text { nedeniyle nicel risk değerlendirme } \\
\text { çalışmalarında } \\
\text { değerlendirilmemiştir. }\end{array}$ \\
\hline 13 & $\begin{array}{l}\text { AKIŞ } \\
\text { YOK }\end{array}$ & \begin{tabular}{|l|} 
Operatör hatası nedeniyle \\
hat üzerinde bulunan \\
manuel vananın kapalı \\
olması
\end{tabular} & $\begin{array}{l}\text { Hatta basıncın artması ile hat } \\
\text { üzerinde bulunan basınç tahliye } \\
\text { vanalarından atmosfere LPG } \\
\text { salınımı ve tutuşturucu kaynak } \\
\text { varlığında parlama / patlama } \\
\text { meydana gelmesi } \\
\text { Frek: [4] } \\
\text { Ktgr: [1] [2] [3] } \\
\text { Şiddt: [2] [1] [2] } \\
\text { Risk: [6] [5] [6] }\end{array}$ & & $\begin{array}{l}\text { Nicel risk analizi çalışmalarında } \\
\text { değerlendirilmiş olup detaylar } \\
\text { FTA 01 / ETA 01'de yer } \\
\text { almaktadır. }\end{array}$ \\
\hline 14 & $\begin{array}{l}\text { AKIȘ } \\
\text { YOK }\end{array}$ & \begin{tabular}{|l|} 
Bakım / test esnasında \\
boru hattında yabancı bir \\
parçanın unutulması veya \\
gemi kaynaklı yabanc1 \\
maddenin hatta girmesi \\
\end{tabular} & $\begin{array}{l}\text { Hatta basinç artı̧̧ yaşanması } \\
\text { Frek: [4] } \\
\text { Ktgr: [1] [2] [3] } \\
\text { Şiddt: [0] [0] [0] } \\
\text { Risk: }[4][4][4]\end{array}$ & & $\begin{array}{l}\text { Risk skoru göz önüne alındığında } \\
\text { kabul edilebilir seviyede olması } \\
\text { nedeniyle nicel risk değerlendirme } \\
\text { çalışmalarında } \\
\text { değerlendirilmemiștir. }\end{array}$ \\
\hline
\end{tabular}


Tablo 3. (Devam ediyor)

\begin{tabular}{|l|l|l|l|l|l|}
\hline 15 & $\begin{array}{l}\text { AKIŞ } \\
\text { YOK }\end{array}$ & $\begin{array}{l}\text { Motorlu kelebek vananın } \\
\text { talep anında açılmaması }\end{array}$ & $\begin{array}{l}\text { Motorlu kelebek vananın kapalı } \\
\text { kalması sonucu hatta basıncın } \\
\text { artması ile hat üzerinde bulunan } \\
\text { basıç tahliye vanalarından } \\
\text { atmosfere LPG salınımı ve } \\
\text { tutuşturucu kaynak varlığında } \\
\text { parlama / patlama meydana } \\
\text { gelmesi }\end{array}$ & $\begin{array}{l}\text { Seviye transmitteri verisi ile } \\
\text { seviyenin artmadı̆̆ sistemden } \\
\text { (kontrol lojik ünite) operatör } \\
\text { tarafindan gözlemlenir, gemi ile } \\
\text { iletişime geçilerek operasyon } \\
\text { durdurulur. }\end{array}$ & $\begin{array}{l}\text { Nicel risk analizi çalışmalarında } \\
\text { değerlendirilmiş olup detaylar } \\
\text { FTA 01 / ETA 01'de yer } \\
\text { almaktadır. }\end{array}$ \\
\hline 16 & $\begin{array}{l}\text { AKIŞ } \\
\text { FAZLA }\end{array}$ & $\begin{array}{l}\text { Frekans konventörü hatas1 } \\
\text { sonucu gemi pompasının } \\
\text { yüksek debide çalışması }\end{array}$ & $\begin{array}{l}\text { Hatta basıç artış yaşanması } \\
\text { Frek: [4] } \\
\text { Ktgr: [1] [2] [3] } \\
\text { Siddt: [0] [0] [0] } \\
\text { Risk: [4] [4] [4] }\end{array}$ & $\begin{array}{l}\text { Sayaç sisteminde yer akış } \\
\text { transmitteri verisi ile akış hızı } \\
\text { kontrol edilir. Gerekli durumda } \\
\text { operatör gemi ile iletişime } \\
\text { geçerek operasyonu durdurur. }\end{array}$ & \\
\hline
\end{tabular}

Tablo 4. LPG Stoklama Terminali Senaryo Listesi

\begin{tabular}{|l|l|}
\hline Senaryo Kodu & Kritik Olay \\
\hline FTA-ETA 01 & $\begin{array}{l}\text { Gemiden Tanka Transferde Hat Üzerinde Bulunan Basınç Tahliye Vanalarından LPG } \\
\text { Salınımı }\end{array}$ \\
\hline FTA-ETA 02 & $\begin{array}{l}\text { Deniz Altındaki Borunun Dış Kaynaklı Sebeplerle Ezilmesi Nedeniyle Boru Çapında } \\
\text { Daralma Olması Sonucu Boru Hattının Zayıf Noktasından LPG Salınımı }\end{array}$ \\
\hline FTA-ETA 03 & $\begin{array}{l}\text { İnsan Hatası Sonucu Yanlış Hesaplama Yapılması ve LPG Tankına Fazla Ürün Transferi } \\
\text { Sonucu Tank Seviyesinin Yükselmesi ile Tankta Yer Alan Basınç Tahliye Vanalarından } \\
\text { Atmosfere Gaz Fazda LPG Salınımı }\end{array}$ \\
\hline $\begin{array}{l}\text { Sınırlayıcı Bariyer } \\
\text { (ETA'da SB olarak } \\
\text { gösterilmiştir.) }\end{array}$ & Gaz dedektörünün devreye girmesi ile operatörün operasyonu durdurması \\
\hline
\end{tabular}

Terminal için toplam 4 kritik olay tanımlanmıştır.

\subsection{Hata Ağacı Analizi}

Hata ağacı analizinde kullanılmak üzere terminaldeki ekipmanların hata frekansları ve yılda yapılan bakım sıklı̆̆ değerleri Tablo 5 'te sunulmuştur.

Tablo 5. Ekipmanlara ait Hata Frekanslarl ve Bakım Siklıkları

\begin{tabular}{|l|l|c|c|c|}
\hline \multirow{5}{*}{ Senaryo Kodu } & Ekipman Adı & $\begin{array}{c}\text { Hata } \\
\text { Frekansı } \\
\text { (/Saat) }\end{array}$ & $\begin{array}{c}\text { Yata } \\
\text { Frekansı } \\
\text { (/Yıl) }\end{array}$ & $\begin{array}{c}\text { Yılda } \\
\text { Yapılan } \\
\text { Bakım } \\
\text { Sıklı̆̆ı } \\
\text { (/Yıl) }\end{array}$ \\
\hline \multirow{5}{*}{ FTA-01 } & Hidrolik Güç Ünitesinde Yer Alan Basınç Transmitteri & $3.000 \mathrm{E}-07$ & $2.628 \mathrm{E}-03$ & 1 \\
\cline { 2 - 5 } & Analog Giriş Modül (Hatası) & $2.500 \mathrm{E}-07$ & $2.190 \mathrm{E}-03$ & 1 \\
\cline { 2 - 5 } & Analog Giriş Kanal (Hatası) & $4.000 \mathrm{E}-08$ & $3.504 \mathrm{E}-04$ & 1 \\
\cline { 2 - 5 } & Ana İ̧lemci (Hatası) & $2.000 \mathrm{E}-06$ & $1.752 \mathrm{E}-02$ & 1 \\
\cline { 2 - 5 } & HGÜ'de Yer Alan Basıç Anahtarı / Switch & $2.000 \mathrm{E}-06$ & $1.752 \mathrm{E}-02$ & 1 \\
\cline { 2 - 5 } & Röle & $2.000 \mathrm{E}-07$ & $1.752 \mathrm{E}-03$ & 1 \\
\cline { 2 - 5 } & HGÜ'de Yer Alan Pompa (Akım Kesici Hatası) & $3.000 \mathrm{E}-07$ & $2.628 \mathrm{E}-03$ & 1 \\
\cline { 2 - 5 } & Motorlu Kelebek Vana (Açıılmaması) & $1.000 \mathrm{E}-07$ & $8.760 \mathrm{E}-04$ & 1 \\
\cline { 2 - 5 } & Seviye Transmitteri & $6.000 \mathrm{E}-07$ & $5.256 \mathrm{E}-03$ & 1 \\
\hline
\end{tabular}


Tablo 5. (Devam ediyor)

\begin{tabular}{|c|c|c|c|c|}
\hline Senaryo Kodu & Ekipman Adı & $\begin{array}{c}\text { Hata } \\
\text { Frekansı } \\
\text { (/Saat) }\end{array}$ & $\begin{array}{c}\text { Hata } \\
\text { Frekansı } \\
\text { (/Yıl) }\end{array}$ & $\begin{array}{c}\text { Yılda } \\
\text { Yapılan } \\
\text { Bakım } \\
\text { Siklığı } \\
\text { (/Yıl) }\end{array}$ \\
\hline \multirow{5}{*}{ FTA-02 } & Seviye Transmitteri & $6.000 \mathrm{E}-07$ & $5.256 \mathrm{E}-03$ & 1 \\
\hline & Analog Giriş Modül (Hatası) & $2.500 \mathrm{E}-07$ & $2.190 \mathrm{E}-03$ & 1 \\
\hline & Analog Giriş Kanal (Hatası) & $4.000 \mathrm{E}-08$ & $3.504 \mathrm{E}-04$ & 1 \\
\hline & Ana İşlemci (Hatası) & $2.000 \mathrm{E}-06$ & $1.752 \mathrm{E}-02$ & 1 \\
\hline & Akış Transmitteri (Hatası) & $6.000 \mathrm{E}-07$ & $5.256 \mathrm{E}-03$ & 1 \\
\hline \multirow{6}{*}{ FTA-03 } & Seviye Transmitteri & $6.000 \mathrm{E}-07$ & $5.256 \mathrm{E}-03$ & 1 \\
\hline & Analog Giriş Modül (Hatası) & $2.500 \mathrm{E}-07$ & $2.190 \mathrm{E}-03$ & 1 \\
\hline & Analog Giriş Kanal (Hatası) & $4.000 \mathrm{E}-08$ & $3.504 \mathrm{E}-04$ & 1 \\
\hline & Ana İşlemci (Hatası) & $2.000 \mathrm{E}-06$ & $1.752 \mathrm{E}-02$ & 1 \\
\hline & Motorlu Vana (Kapanmaması) & $5.000 \mathrm{E}-07$ & $4.380 \mathrm{E}-03$ & 1 \\
\hline & Motorlu Vana (Açılmaması) & $1.000 \mathrm{E}-07$ & $8.760 \mathrm{E}-04$ & 1 \\
\hline \multirow{4}{*}{$\begin{array}{l}\text { Sinırlayıcı Bariyer } \\
\text { (Gaz Dedektörü) }\end{array}$} & Gaz Dedektörü Hatası & $2.200 \mathrm{E}-06$ & $1.927 \mathrm{E}-02$ & 12 \\
\hline & Analog Giriş Modül (Hatası) & $2.500 \mathrm{E}-07$ & $2.190 \mathrm{E}-03$ & 12 \\
\hline & Analog Giriş Kanal (Hatası) & 4.000E-08 & 3.504E-04 & 12 \\
\hline & Ana İşlemci (Hatası) & $2.000 \mathrm{E}-06$ & $1.752 \mathrm{E}-02$ & 12 \\
\hline
\end{tabular}

Sınırlayıcı bariyer dışında bakım sıklığını terminalde yılda 1 olduğu görülmektedir. Her bir senaryo özelinde gerçekleştirilen hata ağacı analizi sırasıyla Şekil 2-5'te verilmiştir.

Şekil 5'ten en yüksek frekans değeri tankta yer alan basınç tahliye vanalarından LPG'nin gaz fazında salınımı kritik olayı için belirlenmiştir.

\subsection{Olay Ağacı Analizi}

Terminal için oluşturulan senaryolar için Olay Ağacı Analizleri ise Şekil 6-8'de sunulmuştur.

Şekil 7'den boru hattının zayıf noktasından LPG salınımı kritik olayı (ETA/02) ile başlayıp, toksik yayılım ile sonuçlanan senaryo en yüksek frekans değerinde bulunmuştur. Herhangi bir yangın, patlama veya toksik yayılım sonucu vermeyen ramak kala olayların frekans değeri dikkat çekicidir.

Olay ağacı analizinde değerlendirilen alevlenir gazlar ve sıvıların kontrolsüz bir şekilde açığa çıktıklarında tutuşma olasılıklarını tahmin etmek üzere ileri analiz teknikleri kullanılarak hesaplamalar yapılır. $\mathrm{Bu}$ hesaplamalar yapılırken Tutuşma Olasılığı Hesaplama Modülü (CCPS'in Probabability of Ignition Calculation Tool) kullanılır. Olay Ağacı Analizi’nde kullanılan olasılıklar aşağıdaki şekilde tanımlanır:

- Ani Tutuşma Olasılığı (Probability of Immediate Ignition - POII),

- Gecikmeli Tutuşma Olasıllğı (Probability of Delayed Ignition - PODI),

- Gecikmeli Tutuşma Sırasında Patlama Olasıllğı (Probability of Explosion Given Delayed İgnition POEGDI)

Tutuşma olasılıklarını tahmin etmek için modül içerisindeki ayrıntılı sonuç veren Seviye 3 (İleri) Analiz algoritması kullanılmıştır. Analizde öncelikle, değerlendirilecek olan alevlenir sıvı ya da gaz hesaplama modülünün kütüphanesinde yer almıyor ise bu maddelere ait kimyasal özellikler (kaynama noktası, parlama 
noktası, minimum tutuşma enerjisi, kendiliğinden tutuşma sıcaklığı ve reaktivite) modül kütüphanesine eklenmiştir. Sonraki adımda senaryo ile ilişkili sızıntı koşullarına dair proses sıcaklı̆̆ı, proses basıncı, sızıntı çap1 ve sızıntı süresi bilgileri modüle girilmiş̧ir. Bu verilerin girilmesi ile sızıntı ile ilgili veriler oluşturulmuştur. Bir sonraki adımda, tutuşturucu kaynak verileri modül içerisine girilmiştir. Açığa çıkan kimyasalın oluşturacağı olay ortamda bulunan tutuşturucu kaynak varlığına göre belirlenmiştir. Ortamda bulunan tutuşturucu kaynaklar; noktasal, hatsal ya da alansal kaynak olarak modülde tanımlıdır. Bu kaynak tiplerinden ortamda mevcut olanlar modül içerisine girilmiştir. Açık ortamlarda son olarak tutuşturucu kaynak kontrolüne ilişkin, kuruluşun aldığı önlemlere (kıvılcım çıkarmayan ekipman, anti statik kıyafet gibi) göre modül içerisinde tanımlanan tutuşturucu kaynak kontrolü (zayıf, orta, iyi) verisi girilmiştir. Kapalı ortamlarda ise havalandırma sistemine dair veriler modül içerisine eklenmiştir. Tüm verilerin girilmesi ile sonuç olasılıkları modül tarafından hesaplanmıştır. ETA-01 için POII-PODI hesaplamaları ekran görüntüleri Şekil 9'da sunulmuştur.

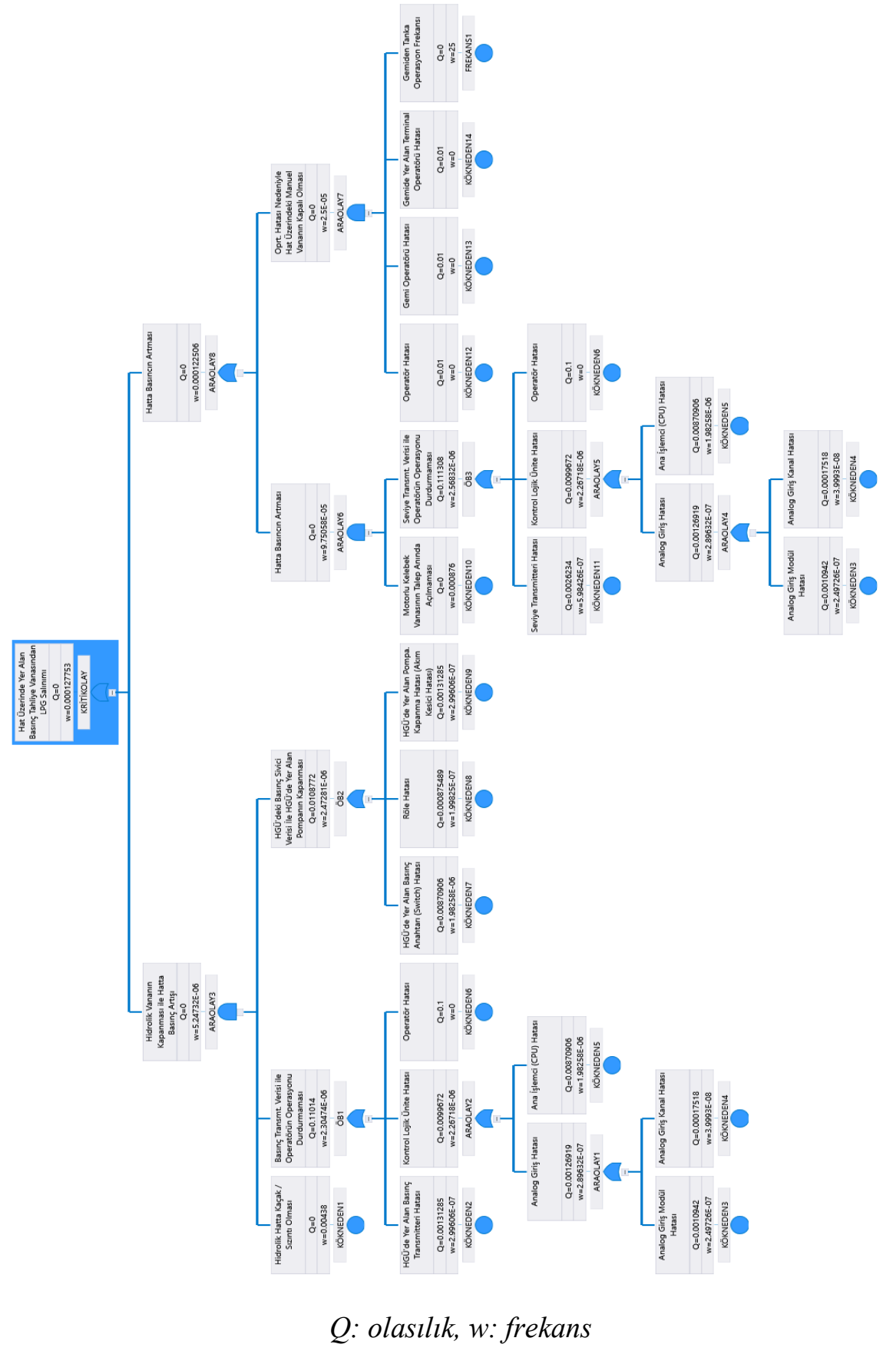

Şekil 2. FTA-01 Hata Ăgacı Analizi 


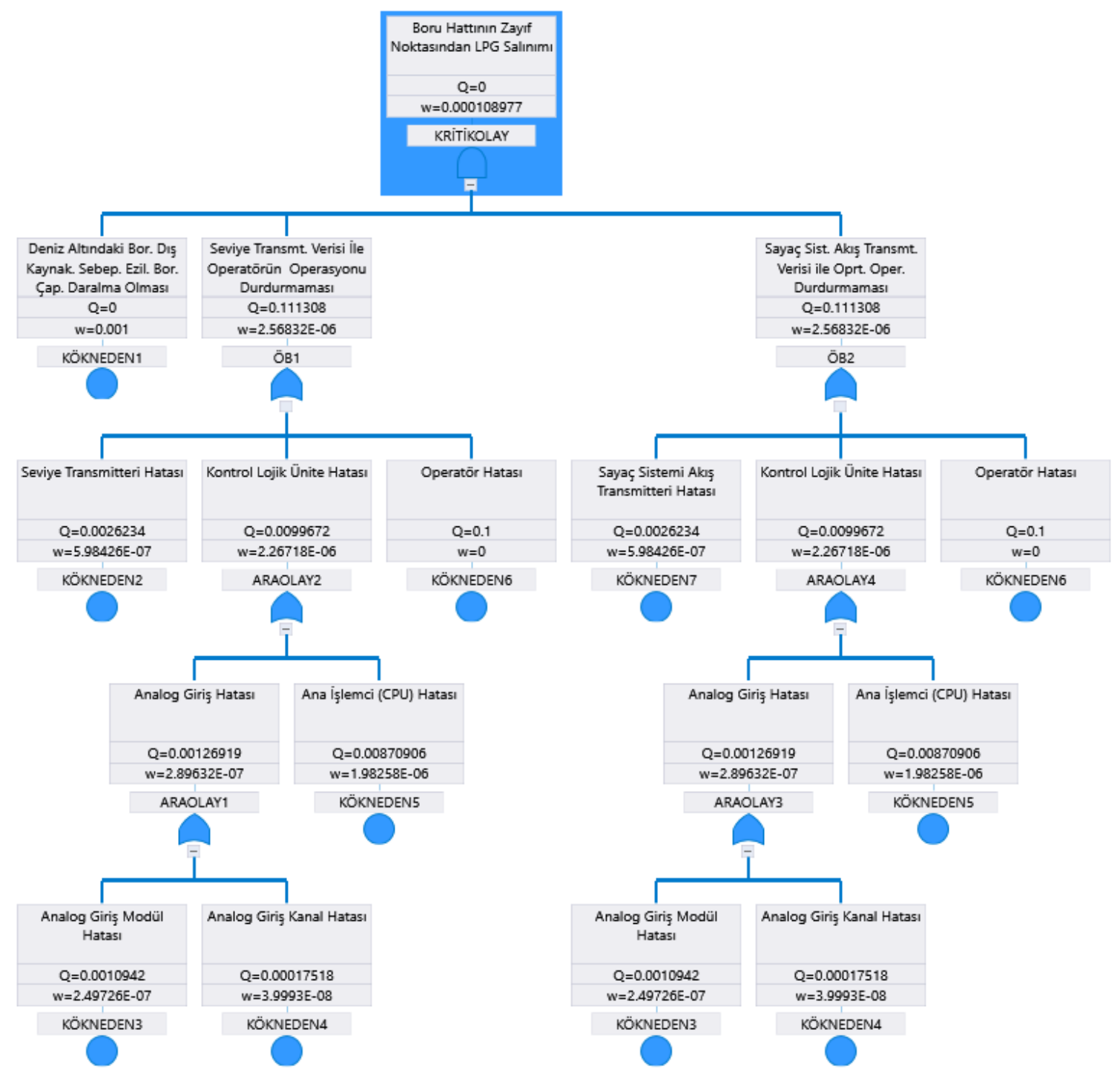

Q: olasılık, w: frekans

Şekil 3. FTA-02 Hata Ağacı Analizi 


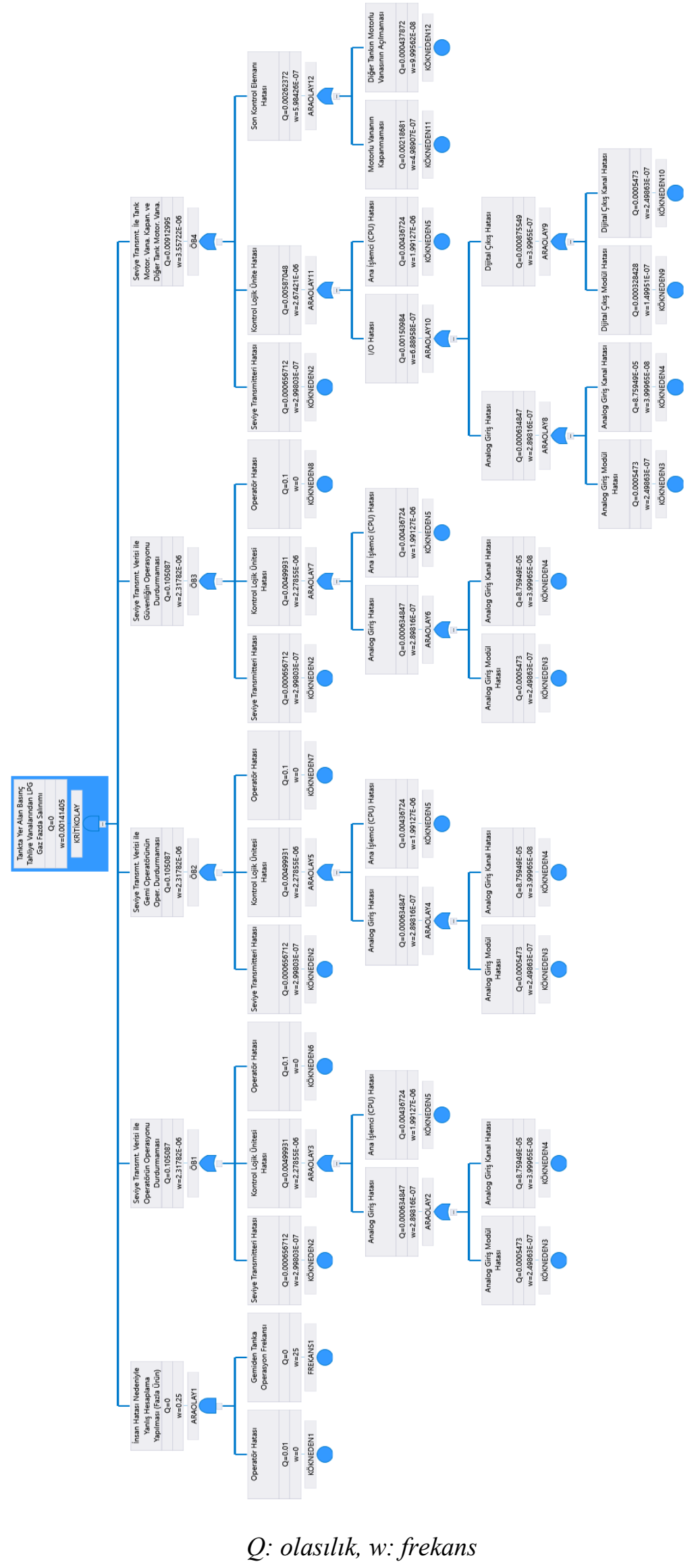

Şekil 4. FTA-03 Hata Ağacı Analizi 


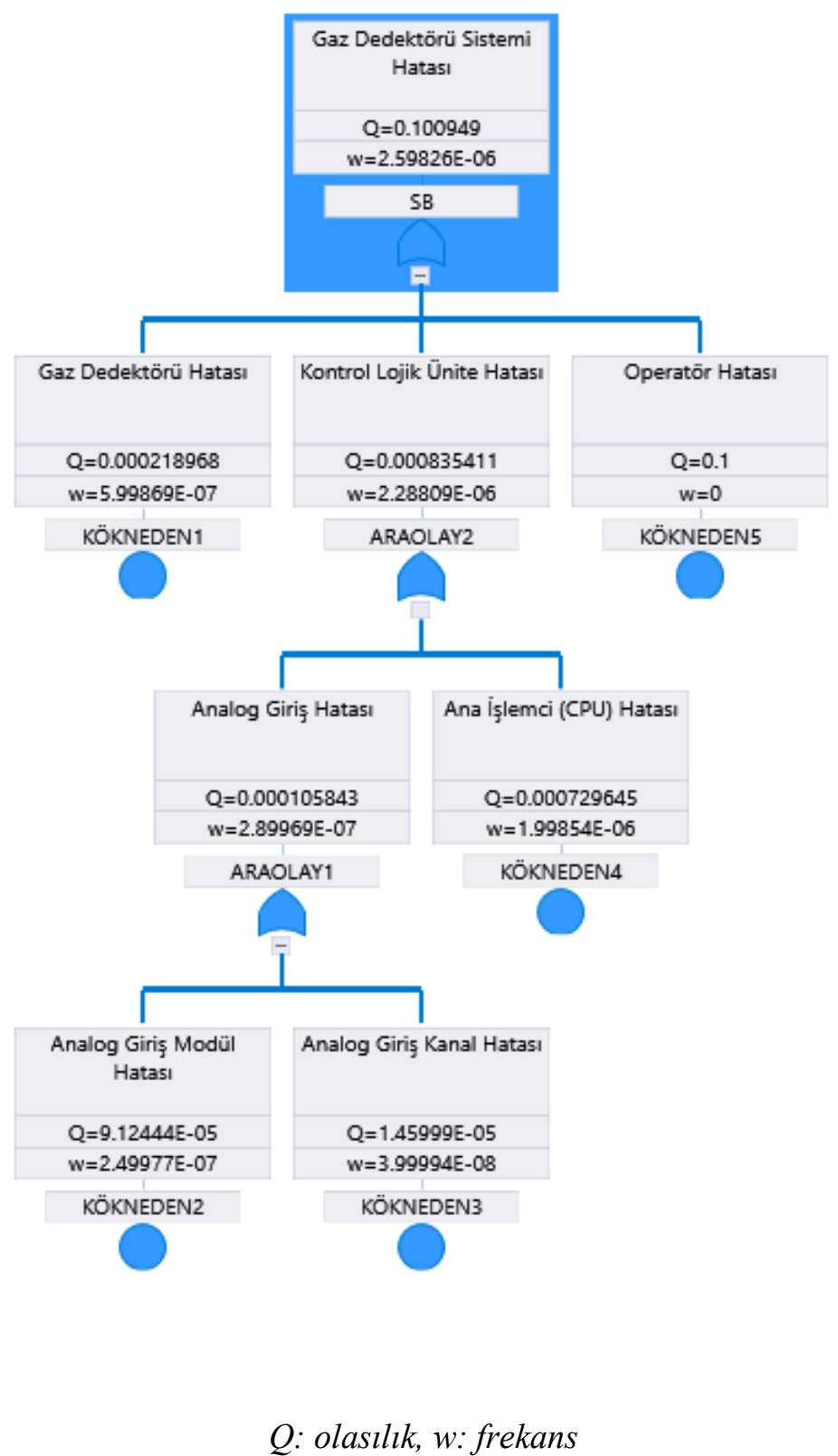

Şekil 5. FTA-04 Hata Ağacı Analizi 


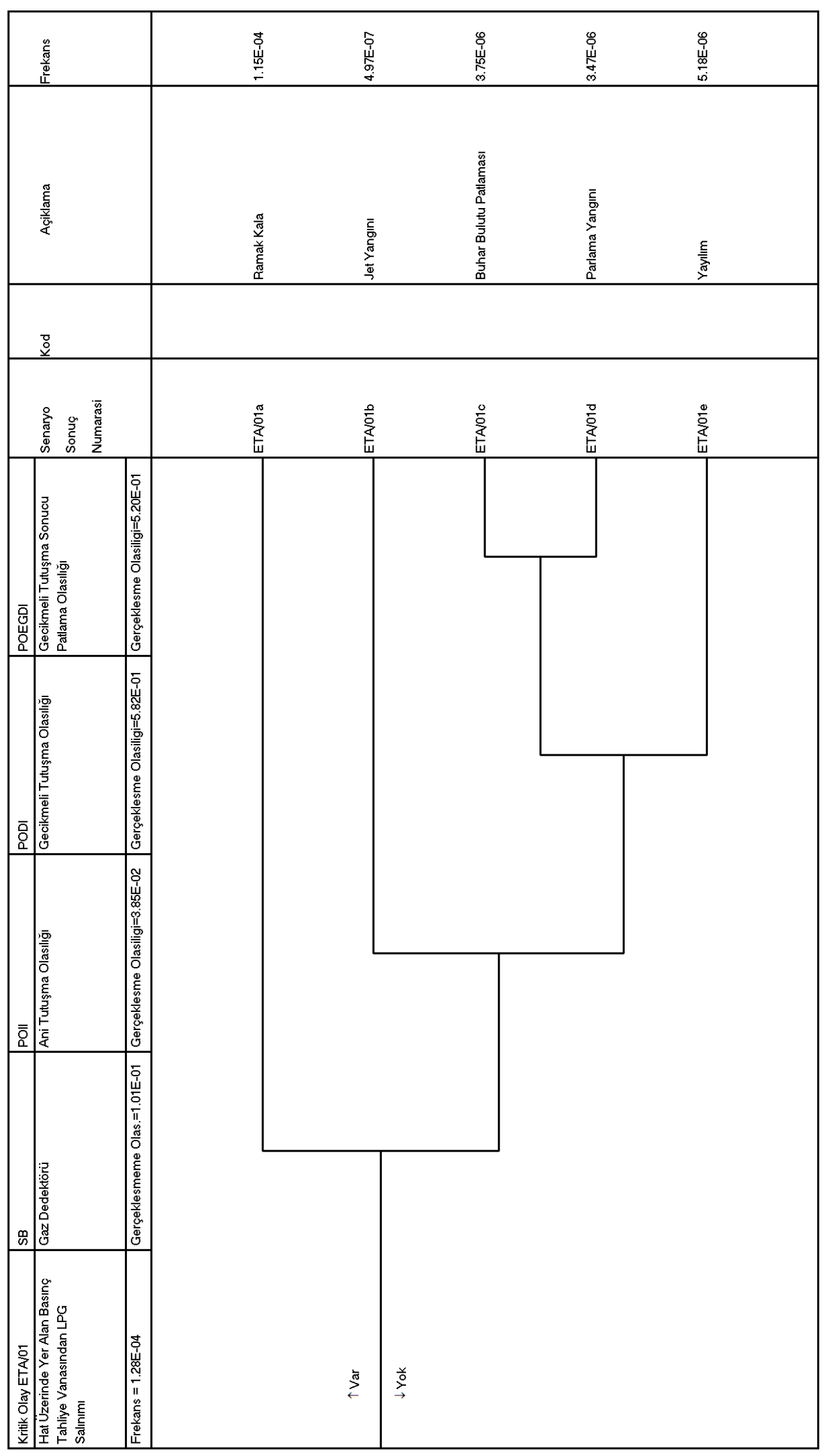

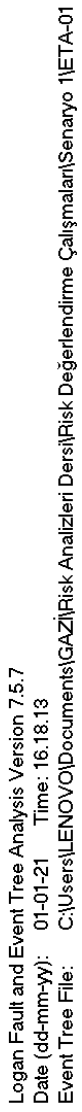

Şekil 6. ETA-01 Olay Ăgacı Analizi 


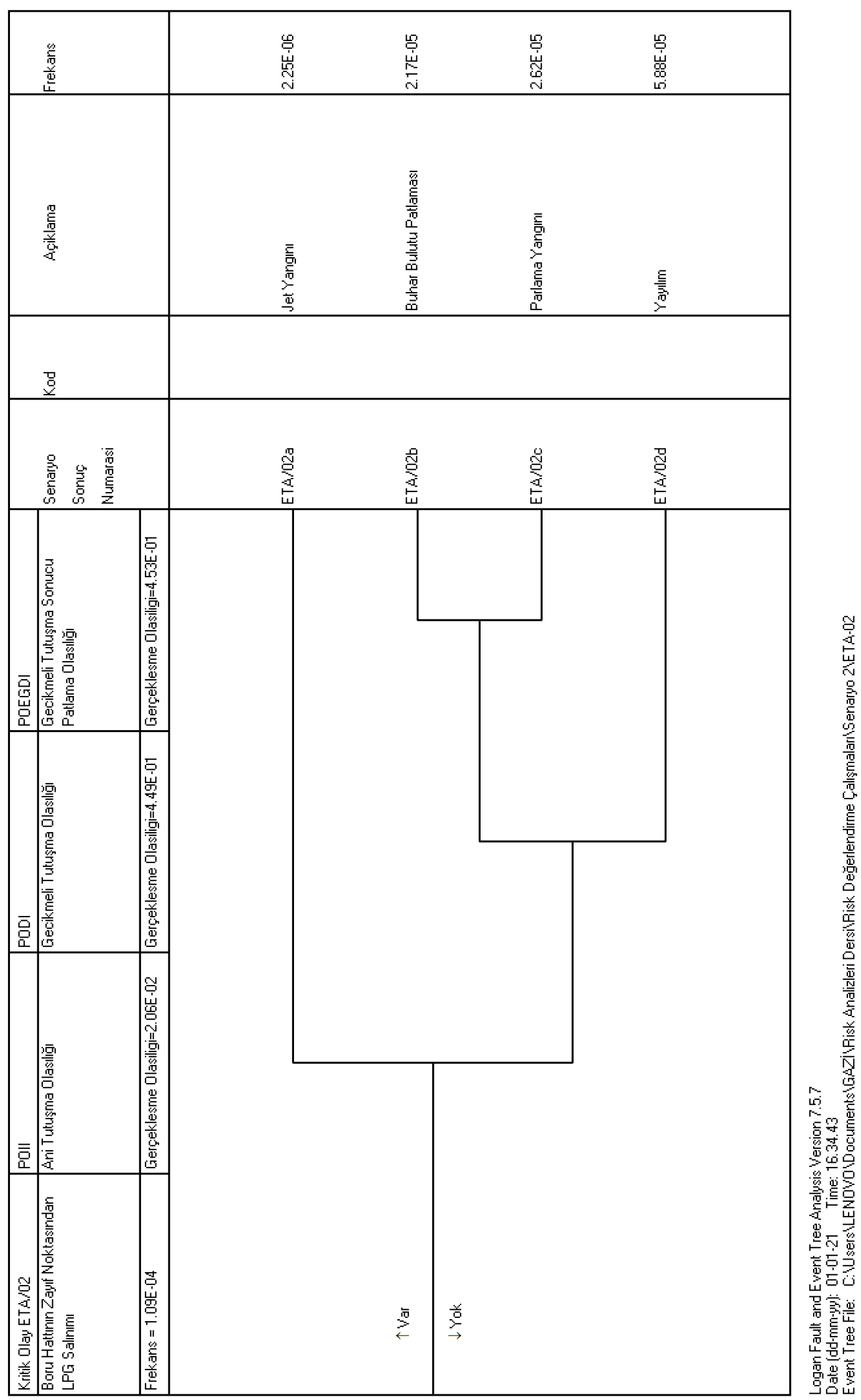

Şekil 7. ETA-02 Olay Ağacı Analizi 


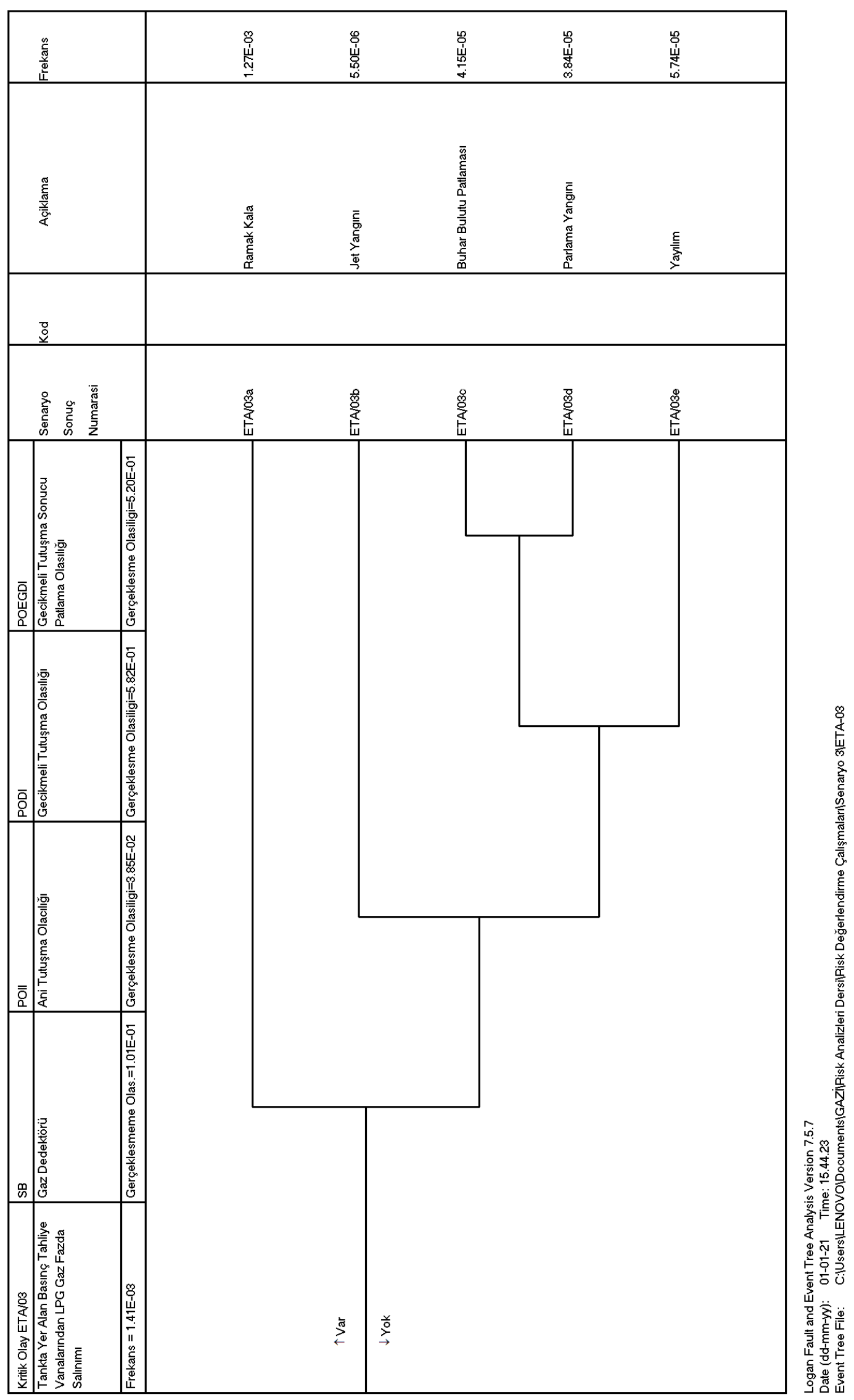

Şekil 8. ETA-03 Olay Ăgacı Analizi 
Probability of Ignition Tool

Read Me | Analysis Level Release Data | Ignition Source | Ignition Control | Ventilation System*1 Material Data

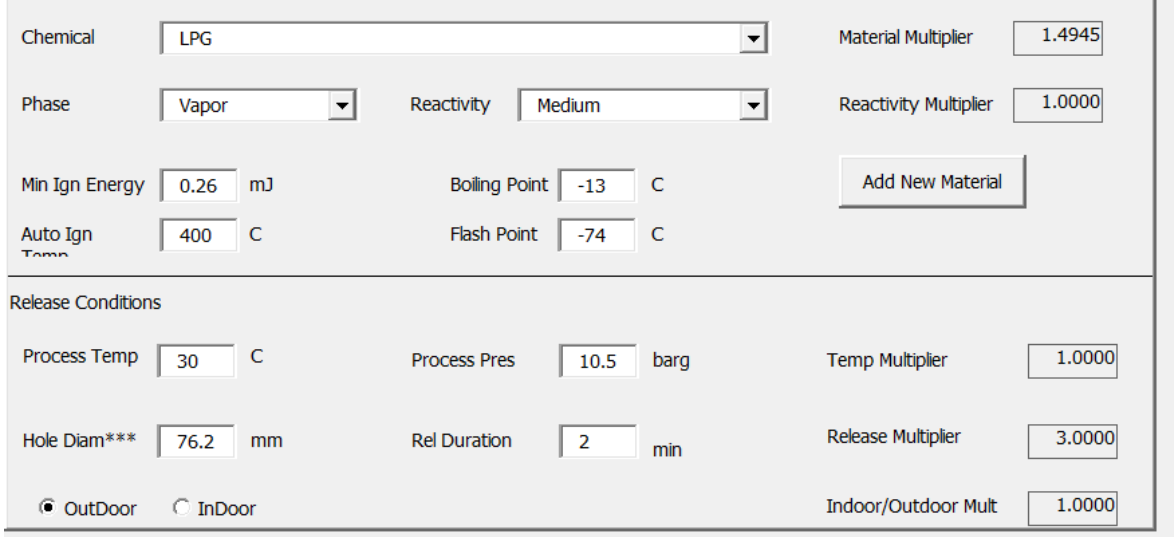

- Ignition C Explosion**

Intermediate Parameters

POIIS

POIII

0.0385

\begin{tabular}{lll} 
& \\
PODI(s/d) & 0.1349 \\
\hline
\end{tabular}

0.0000

POII

PODI

Results

\begin{tabular}{ll} 
Prob Imm Ign (Fire) & 0.0385 \\
\hline
\end{tabular}

Prob Del Ign (Fire or Expl) $\quad 0.582$

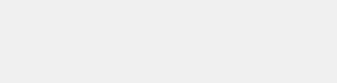

Probability of Ignition Tool

Read Me | Analysis Level Release Data | Ignition Source | Ignition Control | Ventllation System* |

Material Data

\begin{tabular}{|c|c|c|c|c|c|c|c|c|c|}
\hline Chemical & \multicolumn{6}{|l|}{ LPG } & $\nabla$ & Material Multiplier & 1.4945 \\
\hline Phase & Vapor & & - & Reactivity & Medium & & - & Reactivity Multiplier & 1.0000 \\
\hline Min Ign Energy & 0.26 & \multicolumn{2}{|l|}{$\mathrm{mJ}$} & Boliling Point & -13 & C & & Add New Material & \\
\hline $\begin{array}{l}\text { Auto Ign } \\
\text { Tnmnn }\end{array}$ & 400 & C & & Flash Point & -74 & C & & & \\
\hline \multicolumn{10}{|l|}{ Release Conditions } \\
\hline Process Temp & 30 & \multicolumn{2}{|l|}{ C } & Process Pres & 10.5 & \multicolumn{2}{|l|}{ barg } & Temp Multiplier & 1.0000 \\
\hline Hole Diam*** & 76.2 & $\mathrm{~mm}$ & & Rel Duration & 2 & $\min$ & & Release Multiplier & 3.0000 \\
\hline - outDoor & \multicolumn{3}{|c|}{$C$ InDoor } & & & & & Indoor/Outdoor Mult & 1.0000 \\
\hline
\end{tabular}
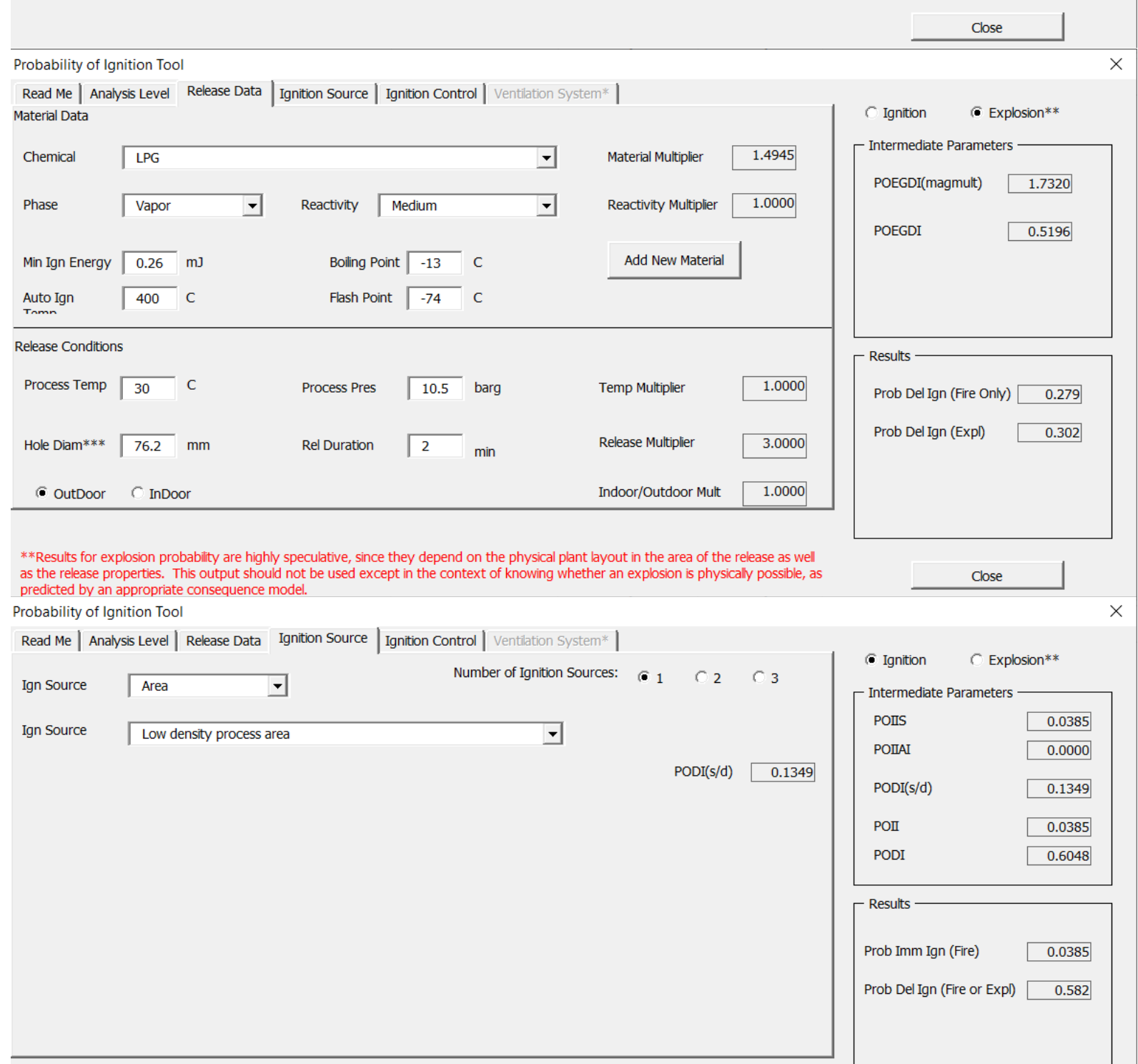

C Ignition Explosion**

- Intermediate Parameters

$\begin{array}{ll}\text { POEGDI(magmult) } & 1.7320\end{array}$

POEGDI

0.5196

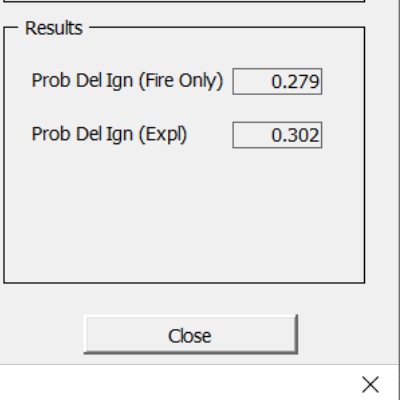

- Ignition $C$ Explosion**

Intermediate Parameters

POIIS

POIIAI

0.0385

0.0000

$\operatorname{PODI}(\mathrm{s} / \mathrm{d})$

0.1349

POI

0.0385

PODI

0.6048

- Results

Prob Imm Ign (Fire)

0.0385

Prob Del Ign (Fire or Expl) $\quad 0.582$ 


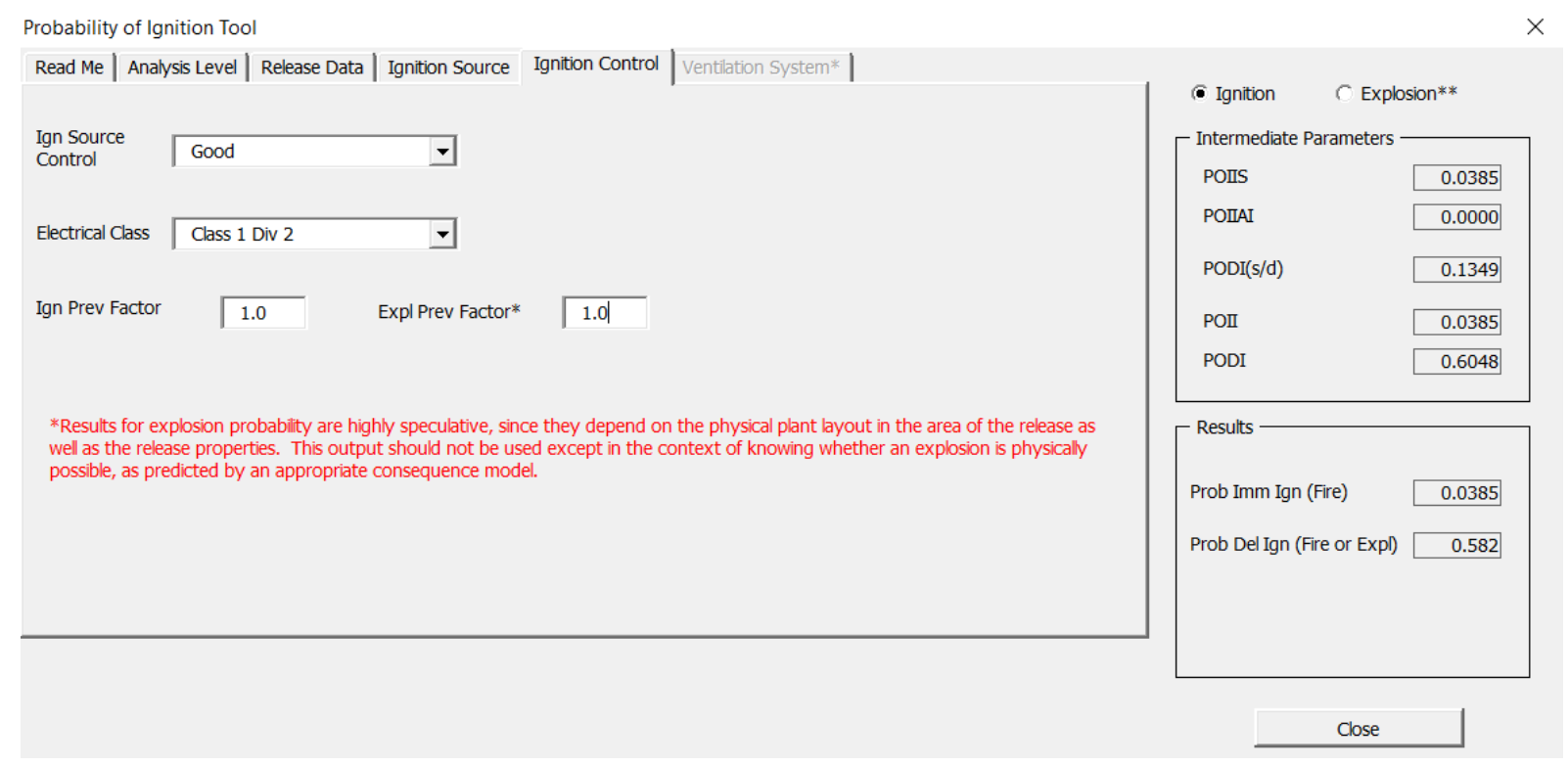

Şekil 9. (Devam Ediyor)

İlgili yazılımda, tutuşma veya patlama durumları için ilgili parametre hesaplaması elde edilmektedir. Kimyasal seçimi, buna ait faz seçimi, salınım koşulları ile ortam özelliklerinin tanımlanması gerekmektedir.

Yapılan risk değerlendirme çalışmaları ile büyük endüstriyel kazaya neden olabilecek senaryolar için hesaplanan frekans değerler Tablo 6' da verilmiştir.

Tablo 6. Senaryolara ait Hesaplanan Frekans Değerleri

\begin{tabular}{|c|c|c|}
\hline $\begin{array}{l}\text { Senaryo } \\
\text { Numarası }\end{array}$ & Senaryo Adı & Büyük Kaza Senaryo Sonucu Frekans \\
\hline \multirow{5}{*}{ FTA-ETA 01} & \multirow{5}{*}{$\begin{array}{l}\text { Gemiden Tanka Transferde Hat Üzerinde Bulunan } \\
\text { Basınç Tahliye Vanalarından LPG Salınımı }\end{array}$} & Ramak Kala: $1.15 \mathrm{E}-04$ \\
\hline & & Jet Yangını: 4.97E-07 \\
\hline & & Buhar Bulutu Patlaması: 8.75E-06 \\
\hline & & Parlama Yangını: 3.47E-06 \\
\hline & & Yay1lım: 5.18E-06 \\
\hline \multirow{4}{*}{ FTA-ETA 02} & \multirow{4}{*}{$\begin{array}{l}\text { Deniz Altındaki Borunun Dış Kaynaklı Sebeplerle } \\
\text { Ezilmesi Nedeniyle Boru Çapında Daralma Olması } \\
\text { Sonucu Boru Hattının Zayıf Noktasından LPG Salınımı }\end{array}$} & Jet Yangını: 2.25E-06 \\
\hline & & Buhar Bulutu Patlaması: 2.17E-05 \\
\hline & & Parlama Yangını: 2.62E-05 \\
\hline & & Yayılım: 5.88E-05 \\
\hline \multirow{5}{*}{ FTA-ETA 03} & \multirow{5}{*}{$\begin{array}{l}\text { İnsan Hatası Sonucu Yanlış Hesaplama Yapılması ve } \\
\text { LPG Tankına Fazla Ürün Transferi Sonucu Tank } \\
\text { Seviyesinin Yükselmesi ile Tankta Yer Alan Basınç } \\
\text { Tahliye Vanalarından Atmosfere Gaz Fazda LPG } \\
\text { Salınımı }\end{array}$} & Ramak Kala: $1.27 \mathrm{E}-03$ \\
\hline & & Jet Yangını: 5.50E-06 \\
\hline & & Buhar Bulutu Patlaması: 4.15E-05 \\
\hline & & Parlama Yangını: 3.84E-05 \\
\hline & & Yayılım: 5.74E-05 \\
\hline
\end{tabular}

Tablo 6'daki frekans değerleri, FTA-ETA 03 senaryosu/ramak kala dışında mevzuatta belirtilen $10^{-4} / \mathrm{y} 1$ eşit frekans değerini karşılar niteliktedir. Ramak kala olayların büyük endüstriyel kaza yaratmayacağı düşünülerek eşik frekans değerini sağlama şartı aranmamaktadır. 


\section{SONUÇLAR}

Çalışmada, LPG stoklama terminalinde gerçekleşen gemiden tanka operasyon için risk analizi çalışmaları yapılmış ve sonuçlar değerlendirilmiştir. Yapılan risk çalışmaları nitel ve nicel olmak üzere iki aşamada gerçekleştirilmiş ve bir metodoloji oluşturulmuştur. Nitel olarak HAZOP, nicel olarak Hata ve Olay Ağacı Analizlerinden yararlanılmıştır. Çalışmada elde edilen her bir büyük kaza senaryo frekans değeri, Yönetmelik Madde 9'da yer alan $10^{-4} /$ yıl eşik frekans değeri ile karşılaştırılmıştır. Eşik frekans değerinden daha düşük belirlenen frekans değerleri, terminalde önlemlerin yeterli ve mevcut önlemlerin kabul edilebilir seviyede olduğunu göstermiştir. Terminalde risk değerlendirmesi sonucu bir yatırım gerekmediği ortaya çıkmıştır. Ancak sistemin devamlılığ önem arz etmektedir. Bu devamlılı̆̆ da sağlamanın yolu test, bakım, periyodik kontrol gibi unsurların her bir ekipman için aksatılmadan gerçekleştirilmesi ile mümkündür. Bu sorumluluk terminale ait olup söz konusu unsurlar gerçekleşmediği takdirde yapılan çalışmaların gerçek hayatta bir karşılığı olmayacaktır.

LPG doğası gereği son derece tehlikelidir ve gerçekleşebilecek kazaların şiddeti de daha büyüktür. Bu büyük endüstriyel kazalar çevreye, insana ve ekipmanlarda ciddi zararlara ve kayıplara neden olmaktadır. Bu kapsamda LPG stoklama terminalleri için proses güvenliği büyük önem arz etmekte olup risk değerlendirme çalışmaları şeffaflıkla yürütülmelidir. Tüm bu çalışmalar esnasında kullanılan veriler gerçek durumu yansıtmalı ve prosese hâkim olan uzman kişilerce gerçekleştirilmelidir.

\section{ÇIKAR ÇATIŞMASI}

Yazarlar çıkar çatışması beyan etmemektedir.

\section{KAYNAKLAR}

Akbar, T. A., Dinariyana, A. A. B., Baheramsyah, A., Prastyasari, F. I., \& Setyorini, P. D. (2019). Risk Assessment on Liquefied Petroleum Gas (LPG) Handling Facility, Case Study: Terminal LPG Semarang. IOP Conference Series: Materials Science and Engineering, 588, 012007.

Akyuz, E., \& Celik, M. (2015). Application of CREAM human reliability model to cargo loading process of LPG tankers. Journal of Loss Prevention in the Process Industries, 34, 39-48. doi:10.1016/j.jlp.2015.01.019

Boult, M. (2000). Risk management of LPG transport activities in Hong Kong. Journal of Hazardous Materials, 71, 85-100. doi:10.1016/S0304-3894(99)00073-4

CCPS, Center for Chemical Process Safety. (2014). Guidelines for Determining the Probability of Ignition of a Released Flammable Mass. John Wiley \& Sons, Inc.

Dinariyana, A. A. B, Artana, K. B., Handani, D. W., Sarasvati, F. I., \& Aprilia, P. W. (2021). Societal risk assessment of terminal and oil refinery unit. IOP Conference Series: Materials Science and Engineering, 1052, 012025 .

Hosseini, N., Givehchi, S., \& Maknoon, R. (2020). Cost-based fire risk assessment in natural gas industry by means of fuzzy FTA and ETA. Journal of Loss Prevention in the Process Industries, 63, 104025. doi:10.1016/j.jlp.2019.104025

James, S., \& Renjith, V. R. (2021) Risk Assessment and Vulnerability Analysis of Liquefied Natural Gas (LNG) Regasification Terminal. Process Integration and Optimization for Sustainability, 5, 99-121. doi: $10.1007 / \mathrm{s} 41660-020-00138-3$

Martins, R. M. S. T., \& Vianna, R. F. (2020). Calculation of Thermal Radiation for the Design of Protection and Fire Fighting Systems for LPG Storage Parks. Brazilian Journal of Petroleum and Gas, 14(1), 33-44. doi:10.5419/bjpg2020-0004

Renjith, V. R., Vijayan, V., \& Soman, S. (2017). Fuzzy Fault Tree Analysis of LPG Cross Country Pipelines -A Case Study. International Journal of Current Trends in Engineering \& Technology, 03(05), 221-227.

Resmî Gazete (2019, 2 Mart). Büyük Endüstriyel Kazaların Önlenmesi ve Etkilerinin Azaltılması Hakkında Yönetmelik (Sayı: 30702). 
Resmî Gazete (2020, 30 Haziran). Büyük Endüstriyel Kazalarla İlgili Hazırlanacak Büyük Kaza Senaryo Dokümanı Tebliği (Sayı: 31171).

Riad, B., Elarkam, M., Ilhem, B., \& Hayett, A. (2020). Risk Asseessment For LPG Storage Tanks Area In Skikda Refinery-ALGERIA Using D-Higraph And Hazop Methods \& Simulation of Dangerous Scenarios Using ALOHA Software. In: 2020 International Conference on Electrical Engineering (ICEE), September 2527, Istanbul, Turkey. doi:10.1109/ICEE49691.2020.9249952

Sachan, S. S., \& Premi, R. (2015). Hazard Identification and Risk Assessment in LPG Bottling Plant. IJSTE International Journal of Science Technology \& Engineering, 1(12), 19-22.

Sarvestani, K., Ahmadi, O., \& Alenjareghi, M. J. (2021). LPG Storage Tank Accidents: Initiating Events, Causes, Scenarios, and Consequences. Journal of Failure Analysis and Prevention, 21, 1305-1314. doi:10.1007/s11668-021-01174-y

Shebeko, Y. N., Bolodian, I. A., Molchanov, V. P., Deshevih, Y. I., Gordienko, D. M., Smolin, I. M., \& Kirillov, D. S. (2007). Fire and explosion risk assessment for large-scale oil export terminal. Journal of Loss Prevention in the Process Industries, 20, 651-658. doi:10.1016/j.jlp.2007.04.008

Spoelstra, M., Mahesh, S., Kooi, E., \& Heezen, P. (2015). Domino effects at LPG and propane storage sites in the Netherlands. Reliability Engineering \& System Safety, 143, 85-90. doi:10.1016/j.ress.2015.06.018

Tauseef, S. M., Abbasi, T., \& Abbasi, S. A. (2010). Risks of Fire and Explosion Associated With the Increasing Use of Liquefied Petroleum Gas. Journal of Failure Analysis and Prevention, 10, 322-333. doi:10.1007/s11668-010-9360-9

TOBB, Türkiye Odalar ve Borsalar Birliği. (2012). Türkiye Sıvılaştırılmış Petrol Gazı Meclisi Sektör Raporu, Ankara, TOBB Yayın Sira No: 2012/174.

Török, Z., Petrescu-Mag, R-M., Mereuță, A., Maloș, C. V., Arghiuș, V-I., \& Ozunu, A. (2020). Analysis of territorial compatibility for Seveso-type sites using different risk assessment methods and GIS technique. Land Use Policy, 95, 103878. doi:10.1016/j.landusepol.2019.02.037

TSE, Türk Standartları Enstitüsü. (2010). Risk Yönetimi - Risk Değerlendirme Teknikleri (IEC / ISO 31010:2009), Ankara.

TSE, Türk Standartları Enstitüsü. (2016) Tehlike ve İşlerliği Çalışmaları (HAZOP Çalışmaları) - Uygulama K1lavuzu (IEC 61882:2016), Ankara. 